\title{
The Determinants of Foreign Trading Volume of Stocks Listed in Multiple Markets
}

Olga Dodd, Christodoulos Louca and Krishna Paudyal*

\begin{abstract}
We examine the determinants of the foreign trading volume of European stocks listed in multiple markets. The results suggest that stocks that cross-list in foreign markets that are larger and more liquid than their home markets, and stocks for which foreign investors acquire information at a lower cost, experience higher volumes of trade in foreign markets. Stocks that are cross-listed in the US are more attractive to foreign traders than those crosslisted in European markets. Differences in motives to trade in American vs. European markets are also uncovered. Among the fundamental motives to trade, diversification benefit and stock risk are more important for investors trading in American markets while the difference in trading costs is more vital for investors in European markets. Among the informational motives to trade, the firm's presence in foreign product markets and the foreign information factor are significant determinants of trading in American markets but not in European markets.
\end{abstract}

Key words: foreign trading volume; cross-listing; multiple market trading; location of equity trading; stock exchange competition; market liquidity; information environment

This version: December 04, 2014

* Olga Dodd (olga.dodd@aut.ac.nz) is from Auckland University of Technology, Christodoulos Louca (christodoulos.louca@cut.ac.cy) is from Cyprus University of 
Technology and a Research Fellow at Durham Business School, and Krishna Paudyal (krishna.paudyal@strath.ac.uk) is from the University of Strathclyde.

\title{
The Determinants of Foreign Trading Volume of Stocks Listed in Multiple Markets
}

\begin{abstract}
We examine the determinants of the foreign trading volume of European stocks listed in multiple markets. The results suggest that stocks that cross-list in foreign markets that are larger and more liquid than their home markets, and stocks for which foreign investors acquire information at a lower cost, experience higher volumes of trade in foreign markets. Stocks that are cross-listed in the US are more attractive to foreign traders than those crosslisted in European markets. Differences in motives to trade in American vs. European markets are also uncovered. Among the fundamental motives to trade, diversification benefit and stock risk are more important for investors trading in American markets while the difference in trading costs is more vital for investors in European markets. Among the informational motives to trade, the firm's presence in foreign product markets and the foreign information factor are significant determinants of trading in American markets but not in European markets.
\end{abstract}

Key words: foreign trading volume; cross-listing; multiple market trading; location of equity trading; stock exchange competition; market liquidity; information environment

This version: December 04, 2014 


\section{The Determinants of Foreign Trading Volume of Stocks Listed in Multiple Markets}

\section{INTRODUCTION}

Extant literature shows that cross-listing enhances firm value but the source of such increment remains elusive. ${ }^{1}$ Corporate managers often suggest that the increase in stocks' liquidity is one of the main sources of value creation through cross-listing (Bancel and Mittoo, 2001) implying that multi-market trading enhances the trading volume. Consistent with this view, Foerster and Karolyi (1998) report that relative to the trading before crosslisting, both the number and value of stocks traded increase substantially after cross-listing, largely due to additional trading in the foreign market. ${ }^{2}$ Baruch et al. (2007) and Halling et al. (2008), however, show evidence of cross-sectional variations in foreign trading activities of cross-listed stocks. In addition, it is also possible that some stocks trade more in a particular foreign market than in other markets due to some stock and/or market specific factors; identifying such factors is the primary objective of this paper. ${ }^{3}$

Understanding factors that affect the level of foreign trading activity of cross-listed stocks in various foreign markets is important for corporate managers, stock exchange regulators and investors. For corporate managers, it helps to identify the characteristics of a foreign stock exchange that may be suitable for cross-listing of their stocks. An active trading of stocks in a foreign market reflects the success of the cross-listing decision as it enhances the liquidity of the stocks in the foreign market, leading to an increase in the firm's ability to raise capital and a widening in its shareholders' base. This, in turn, helps in increasing the value of the firm through reduced cost of capital. In spite of such clear importance, the existing literature says very little, if anything, about the determinants of the location of the foreign trading volume of European stocks that are listed in multiple stock exchanges around the world. From the perspective of the regulators and decision makers of stock exchanges, understanding the factors that affect the distribution of foreign trading volume is important

\footnotetext{
${ }^{1}$ See Gagnon and Karolyi (2010) for a comprehensive review of the literature in the field. Also see Siegel (2005) and Karolyi (2012) for a debate on the possible sources of value enhancement through cross-listing.

${ }^{2}$ More broadly, confirming the importance of stock liquidity as a primary source of cross-listing benefit, the global trading volume of foreign listed stocks reached 175 billion depositary receipts (DRs) with trading value exceeding \$3.8 trillion in 2011 (Bank of New York, 2011).

${ }^{3}$ An equally important issue that deserves a separate study could be which foreign market can enhance the liquidity of stocks of firms with what characteristics.
} 
because attracting foreign companies to list and investors to trade in their markets are closely related to the survival of a stock exchange. In recent years, stock exchanges have been exposed to an unprecedented level of competition. Owing to significant technological and organizational changes, a stock exchange's competitiveness against its industry peers depends on its ability to attract order flows and provide liquidity to investors (Aggarwal, 2002). ${ }^{4}$ When they become aware of the preferences of potential cross-listing firms and investors, stock market regulators can set up provisions that are attractive to their clients corporations as well as investors. Finally, for investors, especially for the arbitrageurs trading in multiple exchanges, knowing how trading volume is apportioned across markets is vital since stocks' liquidity may influence the profitability of their trading strategies mainly through transaction and inventory carrying costs.

This study provides empirical evidence on the determinants of the distribution of foreign trading volume, as measured by the foreign trading volume share, in multi-market trading environments and whether these determinants vary across foreign markets. Based on prior theories on the determinants of trading volume (e.g. Pagano, 1989; Huddart, Hughes and Brunnermeier, 1999), we relate the foreign trading volume share to a number of foreign/home market specific and firm characteristics that represent fundamental and informational motives of trading.

The findings reveal the following patterns. First, on average, a foreign stock exchange attracts $11.4 \%$ of trading volume of a cross-listed stock and this portion is significantly higher for American host markets compared to European host markets (19.2\% vs. 5.8\%). Second, the distribution of foreign trading volume of cross-listed stocks is positively affected by fundamental motives to trade (such as greater market size and market liquidity of the foreign host market relative to the stock's home market and stock risk) as well as informational motives to trade (such as internationally recognised accounting standards used by the crosslisted firm and stock visibility to foreign investors measured by the duration of listing on the foreign host market). The results also show a negative effect of geographic distance between the home and foreign host markets and the intensity of financial analysts' coverage on the foreign trading volume share.

\footnotetext{
${ }^{4}$ For anecdotal evidence on the importance of trading volume for stock exchanges' survival, see "Lack of volume brings end to financial chapter”, The Boston Globe, (October, 3, 2007).
} 
Furthermore, we examine the determinants of the foreign trading volume distribution separately for American and European host markets. The results reveal that the differences in the liquidity of host and home markets, the preparation of financial statements using internationally recognised accounting standards and the intensity of analyst coverage are the common factors that affect the foreign trading volume of sample stocks. However, the significance of other trading motives differs between American and European host markets. In particular, among the fundamental motives, greater diversification benefits and higher stock risk positively affect trading in American host markets, while lower trading cost and the same currency of trading in the home and foreign markets are positively associated with trading volume in European host markets. Among the informational motives of trading, the firm's fraction of foreign sales (exports) and the foreign information factor positively affect the volume of trade in American markets. Regarding European markets, smaller differences in investor protection, a common language and smaller geographic distance between the host and home countries, and the longer duration of foreign listing are positively associated with more active foreign trading.

Finally, we provide evidence for individual host markets. The results suggest that stock risk, a common fundamental factor, and common informational factors (fraction of foreign sales, international accounting standards, the intensity of analyst coverage and foreign (US) information factor) determine the level of trading in cross-listed stocks in two American host markets - the NYSE and Nasdaq. However, differences in the relevance of some factors exist. In particular, greater diversification benefits, the increase in market liquidity and the duration of foreign listing are significant factors for traders in the NYSE but not in Nasdaq. For European host markets, the results reveal that Amsterdam, Frankfurt, London, Paris and Swiss stock exchanges have common determinants of foreign trading activity, such as greater market liquidity and smaller geographic distance. Lower direct costs of trading are associated with more active trading in Amsterdam and Paris, and riskier stocks trade more actively in Frankfurt, Paris and Swiss stock exchanges.

This study contributes to the literature by examining the determinants of foreign trading volumes in multi-market trading environments. This is unique because prior studies focus on the distribution of the trading volume of cross-listed stocks between the US market and their home market (e.g. Baruch et al., 2007; Halling et al., 2008). However, findings on the determinants of trading in the US markets alone cannot be generalized to other host 
markets because US markets differ significantly from other markets in their institutional characteristics and regulations. For example, Doidge, Karolyi and Stulz (2004) argue that, compared to the rest of the world, the US markets provide a high level of liquidity, extremely good investor protection, and the highest disclosure standards. We build on and expand this literature in two important ways. First, we provide a comparative analysis of the fundamental and informational motives of foreign trading volume distribution of European stocks that are cross-listed in several foreign markets. Such analysis is important because according to the World Federation of Exchanges' statistics, non-US stock exchanges are increasingly becoming more important host markets for cross-listed stocks relative to the US stock

exchanges. ${ }^{5}$ Second, we allow the fundamental and informational motives of foreign trading to vary across US and European host markets. In addition, we also provide evidence for individual host markets. This approach enables us to uncover which motives significantly explain the variance of foreign trading volume across different continents and across individual host markets.

The remainder of the study is organized as follows. Section 2 summarizes background theories and develops the hypotheses. Section 3 discusses the data and the sample features. Section 4 presents and discusses empirical results. Finally, section 5 concludes the study.

\section{THEORETICAL FRAMEWORK AND HYPOTHESIS DEVELOPMENT}

The study focuses on two research questions: first, what determines the distribution of foreign trading volume and second, whether these determinants differ among various foreign host markets. Based on prior literature, this section identifies the potential determinants of foreign trading volume in the context of these two research questions.

\subsection{The determinants of the distribution of foreign trading volume}

Theoretical models of multi-market equity trading suggest that trading volume may result either in an equilibrium consisting of all the trading in one market or that competing

\footnotetext{
${ }^{5}$ In particular, in 2011 foreign companies constituted $22.5 \%$ of the total number of listed companies on the New York Stock Exchange (NYSE), 11.1\% on Nasdaq, 20.7\% on the London Stock Exchange (LSE), 10.2\% on Deutsche Börse, $12.9 \%$ on Euronext and $12.1 \%$ on Six Swiss Exchange (SWX). In addition, foreign equity trading contributed significantly to the exchanges' turnover: in 2011 the fraction of foreign equity trading relative to the total value of equity trading (electronic order book trades) was $9.4 \%$ on NYSE, 9.2\% on Nasdaq, 13.8\% on LSE, 3.2\% on Deutsche Börse, 0.3\% on Euronext, and 0.3\% on SWX (data source: http://www.worldexchanges.org/statistics/).
} 
markets may coexist (Pagano, 1989; Huddart et al., 1999). These models show that the distribution of trading volume of cross-listed stocks across the markets arises from several motives of trading which fall broadly into two categories: (i) fundamental motives and (ii) informational motives. To identify the factors that affect the distribution of trading volume across markets, we examine the role of a number of foreign and home market characteristics as well as firm characteristics that relate to these two motives for trading.

\section{[Insert Table I about here]}

\subsubsection{Fundamental motives of trading}

One of the fundamental driving forces of stock selection is the diversification benefit that foreign investors could receive (Solnik, 1974). Cross-listed stocks that exhibit low return correlation with host market returns are likely to be appealing to foreign investors as they enable investors to enhance the risk-return profile of their portfolios. Therefore, the stocks that have lower return correlation with host market returns are likely to have a higher volume of trade in a foreign market. Therefore, we propose our first hypothesis as follows.

H1: Stocks that provide greater diversification benefits to foreign investors have a higher share of trading volume in a foreign market.

In a theoretical work, Pagano (1989) shows that when a stock is traded in several exchanges with different levels of execution costs, trading should migrate to the exchange that has the lowest cost of trading. Accordingly, the difference in the trading costs between foreign and home markets should be inversely related to the foreign trading volume share. Chiyachantana et al. (2004) argue that direct trading costs include explicit costs such as trading commissions and implicit costs such as price impact. Beyond direct costs, however, other indirect trading costs may also arise for several reasons. Firstly, Brennan and Hughes (1991) show that trading costs are inversely related to price per share. ${ }^{6}$ In the context of cross-listings, Pulatkonak and Sofianos (1999) empirically confirm that non-US stocks with a higher US dollar price have a larger US share of trading volume. Such findings imply that stocks with higher price per share (relative to other stocks in the same market) are likely to trade more than stocks with a lower price per share because of lower trading costs. Secondly, larger and more liquid markets are likely to facilitate short selling and margin trading which,

\footnotetext{
${ }^{6}$ Menyah and Paudyal (2000) show that the order processing cost component of the bid-ask spread declines with the increase in price per share.
} 
in turn, is likely to reduce the indirect costs of such trades and lead to higher trading volume. Consistent with the view that corporate managers care about these costs, Fernandes and Giannetti (2014) provide evidence that host market size and liquidity are positively related to the probability of cross-listing. Therefore, we anticipate a positive relation between the foreign trading volume share and the host to home market ratios of market size and market turnover. Finally, in the models of Chowdhry and Nanda (1991) and Madhavan (1995), informed investors and large liquidity traders benefit by splitting trades across the markets. However, if they have to trade in different currencies, then the currency fluctuation risk and conversion costs are likely to deter traders, leading to lower trading volume. Consequently, stocks that are traded in the same currencies in foreign host and home markets are likely to have more trading in foreign markets than stocks that trade in different currencies in different markets. We formulate the following hypothesis to summarize the above arguments.

H2: Stocks with lower costs of trading in a foreign market, relative to the cost of trading in the home market, have a higher share of trading volume in the foreign market.

Another factor that is likely to affect the distribution of trading volume is the risk of the stock itself (Halling et al., 2008). For foreign investors it is more difficult to acquire relevant and accurate information about a company, thus adding further exposure to risk. This could be more severe in the cases of firms with higher risk. Therefore, foreign investors are likely to be less enthusiastic about trading on foreign stocks that are more risky. On the other hand, riskier companies have higher levels of prediction error, and thus, the rebalancing needs of foreign investors increase, leading to more active trading (Chordia, Huh and Subrahmanyam, 2007). Further, Abdallah and Goergen (2008) show that stocks with higher risk have a higher propensity to cross-list in more developed markets, providing indirect evidence of the attractiveness of high-risk stocks to foreign investors. We tentatively expect a positive relation between stock risk and foreign trading volume due to frequent rebalancing needs, but have in mind that the relation could also be negative due to the reluctance of foreign investors to trade in high risk assets, or even insignificant when the effects of foreign investors' reluctance to trade and rebalancing needs cancel each other out. Therefore, we would like to test the following hypothesis.

H3: Riskier stocks have a higher share of trading volume in the foreign market.

\subsubsection{Informational motives of trading}


Investors are likely to trade in a market where information is readily available and is transparent, rather than in a market where information is obscure and difficult to obtain. Huddart et al. (1999) show that in equilibrium, liquidity traders choose to trade only on the exchange with the strictest disclosure requirements because the informational advantage of rent seeking insiders is less in such markets. Therefore, the quality of the information environment in host/home markets should affect the location of trading.

The quality of the information environment largely depends on the quality of the legal environment and the enforcement of regulations (Ball, 2006; Soderstrom and Sun, 2007). A weaker legal investor protection empowers corporate managers to seize private benefits of control and, accordingly, increases the costs of owning and trading the stocks for investors (Shleifer and Vishny, 1997). When a stock is traded in more than one market and with different levels of investor protection, investors will trade in the market with the better legal protection (Huddart et al., 1999). Therefore, the foreign trading volume share should be positively related to the difference in investor protection between host and home markets.

Another important aspect of the legal environment is the presence and quality of insider trading regulations enforcement. Numerous studies on the effects of insider trading rules provide evidence that insider regulations reduce the amount of trading based on private information (Durnev and Nain, 2007), decrease investors' adverse selection costs (Fischer, 1992), improve investor confidence by providing incentives for corporate managers to disclose information (Maug, 2002), and enhance stock price informativeness and market liquidity (Fernandes and Ferreira, 2009). Along this line, Bhattacharya and Daouk (2002) suggest that it is the enforcement of insider trading regulations, rather than their mere existence, that actually brings positive consequences to capital markets. Therefore, the volume of trade in a foreign market that exhibits better enforcement of insider trading regulations than in a home market is expected to be higher. Our fourth hypothesis is as follows.

H4: A foreign market with a stronger legal environment, relative to the home market, attracts a higher share of trading volume of cross-listed stocks.

Domowitz, Glen and Madhavan (1998) argue that the location of trading also depends on the cost of acquiring information. Owing to cross-border constraints, such as differences in languages, geographic distance, and lack of familiarity with the company, foreign investors 
are likely to have only limited information and face a higher cost of access to information. Pirinsky and Wang (2006) argue that informed trading should concentrate on the market closest to the company's headquarters, i.e. the home market, where value-relevant information is more likely to be produced. Similarly, if financial information is first revealed in the home market then local investors may exploit the information in the local market before foreign investors can act upon it. In both cases, the cost of information acquisition becomes higher for foreign investors. Therefore, as argued by Coval and Moskowitz (1999), foreign investors tend to invest in stocks that are familiar to them. Similarly, Grinblatt and Keloharju (2001) show that investors are more likely to invest in stocks of companies that communicate in the investor's native language and that investors' equity trading activity is negatively related to the geographic distance between the investor's location and the company's headquarters. ${ }^{7}$ Thus, familiarity alleviates the problem of an information barrier between host and home markets which, in turn, reduces the informational advantage of domestic traders over foreign traders. The informational advantage of domestic traders, relative to foreign traders, may also become less when value-relevant information is produced abroad. This can happen when a considerable part of both current and future cash flows of the company depends primarily on the economic conditions of the foreign market (such as the cases of export oriented companies). Consistent with these views, Sarkissian and Schill (2004) argue that corporate managers anticipate that foreign investors would be reluctant to invest in unfamiliar foreign stocks and, therefore, tend to cross-list in more proximate markets. Hence, a common language, a smaller geographic distance between host and home markets, and higher fraction of foreign sales should lead to more active foreign market trading of a cross-listed stock.

Companies motivated to improve their international liquidity may also voluntarily reduce the cost of acquiring information, especially for foreign investors, by reporting financial information using International Accounting Standards (IAS) or US Generally Accepted Accounting Principles (GAAP). Accordingly, companies that prepare financial reports using such accounting standards should be more likely to develop an active foreign market relative to companies that prepare financial statements only under local accounting

\footnotetext{
${ }^{7}$ Geographic distance between the host and home countries is closely related to the difference in time zones between the host and home countries. According to Pulatkonak and Sofianos (1999), the time zone difference is the most significant determinant of foreign trading volume on the NYSE. In the case of the European stocks traded within continental Europe, the time zone difference is less relevant as all continental Western European countries (with the exception of Portugal) are in the same time zone.
} 
standards. Another factor that affects the firm's information environment is financial analysts' following. Analysts generate and disseminate firm-related information to the markets. Therefore, firms that have more extensive analyst coverage should have less information asymmetry (Draper and Paudyal, 2008) and, therefore, less active trading of their stocks. On the other hand, if financial analysts systematically make errors in their forecasts, consequent revisions should generate more active stock trading. The cost of acquiring information by foreign investors may also depend on the firm's visibility. Companies' visibility can increase with the duration of trading (Chordia et al., 2007). Therefore, the number of years listed on the foreign exchange should be positively associated with trading in foreign markets. Based on the discussion of the importance of the cost of acquiring information, we formulate the following hypothesis.

H5: Stocks, for which foreign investors acquire information at a lower cost, have a higher share of trading volume in the foreign market.

Finally, Baruch et al. (2007) argue that the trading activity of cross-listed stocks is related to an information factor that quantifies the marginal contribution of the foreign market's returns in explaining the stock's returns. The fundamental forces underlying this relation, although still remaining elusive, are likely to correlate with foreign investor familiarity, reflecting the nature of the firm's business activities related to geography or industry membership. Based on the argument of Baruch et al. (2007), stocks with a higher foreign information factor should have a higher share of trading on the relevant foreign market. Therefore, we formulate our sixth hypothesis as follows.

H6: Stocks with a higher foreign information factor have a higher share of trading volume in the foreign market.

Table I summarizes the possible factors and their expected impact on the distribution of foreign trading volume across the markets, and Appendix A defines the variables.

\section{DATA AND DESCRIPTIVE ANALYSIS}

\subsection{Data}


The sample consists of European companies that were cross-listed on at least one major foreign stock exchange during 1990-2007. We focus on European cross-listed firms because such firms face some degree of homogeneity in the trading environment in their home markets and other European markets owing to European rules and regulations that have been harmonised particularly in more recent years. Homogeneity, in turn, enables us to more accurately compare whether the determinants of foreign trading volume distribution vary across American and European host markets. Data on cross-listings were hand collected from various sources including the stock exchanges’ websites, Factiva news database, the foreign listings data set of Sarkissian and Schill (2004), and the databases on DRs from the Bank of New York, Citibank, Deutsche Bank and JP Morgan. Since we are interested only in listings on regulated exchanges, we include only ADRs (American Depositary Receipts) Levels II and III. Data on trading volume and stock prices were obtained from Datastream. Since the study aims to analyze common equity only, preference shares are excluded. In addition, if a company has more than one class of common share (e.g. class A and class B, with different voting rights) we include only the major security of the company, as indicated in Datastream. Furthermore, to avoid the implications of unique price pattern and trading behavior of initial public issues, as in previous studies, we exclude initial public offers made in a foreign market. Finally, we also exclude companies that do not have full information on key variables of interest, such as the distribution of trading volume and their determinants. The sample includes cross-listings in the major foreign exchanges, the main foreign trading venues for European cross-listed stocks in American (NYSE and Nasdaq) and European (Amsterdam, Frankfurt, London, Paris and Swiss) stock exchanges. ${ }^{8}$ The final sample consists of 254 European companies from 15 different countries with 388 foreign listings traded on seven foreign exchanges. A sample stock, on average, has 1.5 foreign listings, i.e. is listed on more than one foreign exchange. We treat each foreign listing independently.

Table II presents the distribution of the sample companies by home and host markets. The table shows that a large number of the cross-listed companies originate from the UK (62 or $24.4 \%$ of the sample) followed by Ireland (39 or $15.3 \%$ of the sample) and Germany (33 or $13.0 \%$ of the sample). Out of the total of 388 foreign listings, 113 are in the US stock exchanges and 275 in European exchanges. The largest contributor to the US listings is the

\footnotetext{
${ }^{8}$ Initially we identified over 20 regulated equity markets where foreign trading of European stocks takes place. Out of all the foreign host markets we focus on major markets that contribute at least $2 \%$ of the total equity trading volume of the sample stocks. The seven host exchanges included in the sample account for more than $90 \%$ of the foreign trading volume of European cross-listed stocks.
} 
UK with 42 listings (37.2\% of US cross-listings), while the largest contributor to European listings is Germany with 56 listings (20.4\% of European cross-listings). Among the companies that cross-list in the US, more than two thirds (81 listings or 71.7\%) list in the NYSE. Among the companies that are cross-listed in Europe, 85 (30.9\%) are listed on the London stock exchange (LSE) and 63 (22.9\%) in Paris. The shares of the rest of the stock exchanges are randomly distributed without any noticeable concentration.

[Insert Table II about here]

\subsection{Descriptive Analysis}

Building on the theoretical discussion in Section 2, this section provides information on the major features of the variables analyzed in this study. Appendix A provides detailed definitions and data sources of the variables used. To improve the exposition, the variables are categorized into three sets: (a) the dependent variable, i.e. the foreign trading volume share of sample stocks, (b) the determinants (factors representing fundamental and informational motives) of the distribution of the foreign trading volume share, and (c) the control variables that are known to affect stock trading in general. Table III presents summary statistics of all the variables.

\section{The dependent variable}

The dependent variable, the foreign trading volume share $\left(F T V S_{i, n, t}\right)$, is the monthly ratio of the number of shares traded in a foreign market divided by the total number of the shares traded in the same month in all markets in the sample, including the stock's home market and foreign markets where the stock is listed, as in equation (1):

$$
\mathrm{FTVS}_{i, n, t}=\frac{N S T_{i, n, t}}{N S T_{i, d, t}+\sum_{n} N S T_{i, n, t}}
$$

where $N S T_{i, n, t}$ is the number of shares of stock $i$ traded on foreign exchange $n$ during the month $t$, and $N S T_{i, d, t}$ is the number of shares of stock $i$ traded on the home market $d$ during the month $t$. By using the number of shares traded, instead of the dollar value of the trade, we eliminate potential biases caused by the fluctuations in the exchange rate between domestic and foreign currency. Further, when trading on a foreign stock exchange takes place in the 
form of a DR, the number of traded shares is adjusted using the DR conversion ratio. We also adjust the number of traded shares, when prompted, for changes in conversion ratios over time. Finally, to account for potential double counting of trading volume in dealer markets, we follow Abdallah, Abdallah and Saad (2011) and Anderson and Dyl (2005). In particular, for Nasdaq and LSE we multiplied the reported trading volume data by 0.55 for high-volume stocks and 0.77 for low-volume stocks. Stocks are classified as high (low)-volume if the reported trading volume is more (less) than 140,000 shares per day. ${ }^{9}$

The statistics in Table III show that for the full sample, the average FTVS ratio is $11.4 \%$ (i.e. on average, $11.4 \%$ of the stock's total trading volume takes place on a foreign market). However, there is also a significant variation in the distribution of the FTVS by the host market - for American host markets the average share is 19.2\% while for European host markets it is $5.8 \%$. American markets seem to be more successful in attracting trading of foreign stocks than European markets.

[Insert Table III about here]

Figure I shows the monthly average 'foreign trading volume share' in the five years after cross-listing for the full sample and for American and European host markets subsamples. The mean foreign trading volume share in the first five years after cross-listing for the full sample fluctuates between $4.4 \%$ and $12.7 \%$. For American host markets it increases substantially in the first two months after cross-listing, declines slightly in the next several months and then fluctuates between $12.9 \%$ and $23.0 \%$. The European share of trading volume peaks in the second year (6.0\%) after cross-listing and then fluctuates between $2.2 \%$ and $6.0 \%$.

[Insert Figure I about here]

Table III also reports the mean and median foreign trading volume share of individual stock exchanges. Among the American host markets, Nasdaq has a higher share of trading than the NYSE (average 22.8\% vs. 18.1\%). Among European host markets, the LSE has the highest share of trading (average 12.7\%) while Frankfurt Stock Exchange has the lowest (average $0.8 \%$ ).

\footnotetext{
${ }^{9}$ We would like to thank the referee for pointing out the issue of potential double counting in dealer markets and for suggesting the adjustment method.
} 


\section{Factors representing fundamental motives}

The average correlation between the stock's weekly returns and the foreign market returns (return correlation), a measure of diversification benefit to foreign investors, is 0.42 (Table III), indicating that foreign investors may improve the risk return trade-off position of their portfolios by investing in cross-listed companies. The average return correlation of the sample stocks with American markets is less than the correlation with European markets (0.38 vs. 0.45 ). The estimates also show that the average cost of trading in a foreign market is lower than the cost of trading in the home market (average trading cost difference is negative $-0.03 \%)$ and the reduction in trading cost is greater for European cross-listings $(-0.08 \%)$ rather than US cross-listings (a positive trading cost difference of $0.04 \%$ means trading cost in the host market is greater than in the stock's home market). The reduction in trading cost from cross-listing in Europe is driven by cross-listings in the LSE (-0.27\%). The average price per share of stocks is $£ 20.04$ and it is higher for European host markets than for American host markets (£17.46 vs. £21.90). The average price per share is particularly low for Nasdaq listings (£11.91). The average size of foreign markets is significantly larger (14.83 times) (market size difference) compared to the size of the home markets of the sample stocks. This difference is largely driven by the size of American host markets (25.98 times). Among European listings, the LSE listings have the largest average market size difference (19.57 times). The average turnover ratio of foreign markets is 6.27 times that of the home markets (market turnover difference) and the difference is larger for European host markets (6.84 times) compared to American host markets (5.47 times). On average, 37\% of stocks have the same currency of trading (same currency indicator) between host and home markets, contributed exclusively by European cross-listings (63\%) as trading in the US takes place in US dollars (same currency indicator is $0 \%$ ). The average standard deviation of stock returns (stock risk) is 0.05, both for stocks cross-listed in American and European host markets.

\section{Factors representing informational motives}

A foreign market in the sample on average exhibits a stronger investor protection compared to the home market, as indicated by a positive value (0.21) of investor protection difference, which is the difference in the investor protection index of La Porta et al. (2006) between the host and home countries (Table III). The improvement in investor protection is greater for US cross-listings (0.45) compared to European cross-listings (0.03). Cross-listings in the Nasdaq entail the most significant improvement in investor protection compared to the 
home market (0.46), while cross-listings in Frankfurt are not associated with an improvement in investor protection - a negative difference indicates that a foreign host market has a weaker investor protection than the home market. The estimates show that about $15 \%$ of the listings take place in host markets with enforced insider trading regulations relative to the home market (enforced insider trading laws difference); this statistic is higher for European host markets (19\%) compared to American host markets (9\%). The LSE has the highest proportion of listings that take place in the host market with enforced insider trading regulations relative to the home market (58\%). A considerable number of cross-listings (33\%) take place in foreign countries that share the same language as the stock's home country (common language). This number is more than twice as high for American host markets (48\%) as it is for European host markets (23\%). Among European cross-listings, listings in the LSE are associated with the highest common language indicator (58\%). The average geographic distance is about $2,900 \mathrm{~km}$, driven mainly by the distance between the European home markets of the sample stocks and the US - the average geographic distance between a US market and a European home market is $6,150 \mathrm{~km}$. The average geographic distance for European host markets is $550 \mathrm{~km}$. The estimates also show that cross-listed companies are characterized by strong export orientation, as indicated by the average foreign sales ratio of $59 \%$ for the full sample and for both American and European host markets. About $45 \%$ of the sample companies prepare financial statements using IAS/US GAAP (accounting standards), slightly more by companies cross-listed in European markets than in American markets (47\% vs. 42\%, respectively). A sample stock on average has 18.93 oneyear, earnings per share (EPS) financial analysts' forecasts (analyst coverage), the same for American and European host markets. Average financial analyst forecast error is 1.32 and is significantly lower for American cross-listings than for European cross-listings (0.89 vs. 1.64). On average, a sample stock has been listed in a foreign market for 7.46 years (duration of listing). It is also notable that companies listed in the US have been in foreign markets for a longer period (8.78 years) than the companies cross-listed in Europe (6.51 years). Finally, the average foreign information factor, calculated using the method proposed by Baruch et al. (2007), is 2.54 for the full sample and is higher for European than for American host markets (2.73 vs. 2.28).

\section{Control variables}


We also control for other factors that are identified in the literature as responsible for determining the volume of trade, but without a clear ex ante prediction regarding the distribution of foreign to total trading volume. Investors are likely to need to spend less on acquiring information about large companies as they reveal more information to the public, experience more intensive media coverage, have larger advertising budgets, and are followed by more analysts (Aggarwal, Klapper and Wysocki, 2005). The average market value of a firm in the sample (company size) is $£ 17.19$ billion (Table III). The firms that cross-list in the US are slightly larger ( $£ 17.52$ billion) than the firms that cross-list in Europe ( $£ 16.95$ billion). Firms with higher growth opportunities may face a greater need to raise external capital. Raising capital, in turn, increases the investor base and makes a company more visible to investors (Reese and Weisbach, 2002). The average market-to-book ratio, a measure of growth opportunities, of the sample firms is 4.27, and companies with higher growth opportunities cross-list more often in American than European markets (5.36 vs. 3.48). Some stocks in the sample are traded on more than one foreign exchange. To control for multiple foreign listings that potentially reduce the share of trading on each exchange, we include the number of foreign exchanges where the stock is traded in a particular month as an additional control variable ( $N$ foreign listings). It varies from one to six with the average and median around two. The greater the number of foreign exchanges where the stock is traded simultaneously, the lower the share of trading of each of the foreign exchanges. To control for potentially different levels of trading activity in cross-listed stocks in the US and non-US markets we include a host US variable. In our sample about $42 \%$ of observations are contributed by cross-listings in the US.

\section{THE REGRESSION RESULTS}

\subsection{The Factors Affecting the Distribution of Foreign Trading Volume}

This section presents and discusses the results of our empirical investigation of the determinants of the distribution of trading volume of the cross-listed stocks between foreign and domestic markets in a multivariate framework. Particularly, we estimate equation (2) using the ordinary least squares regression method.

$$
\operatorname{Ln}\left(\mathrm{FTVS}_{i, n, t} /\left(1-\mathrm{FTVS}_{i, n, t}\right)=\gamma_{0}+\sum_{j=1}^{J} \gamma_{j} X_{j, i, n, t}+\varepsilon_{i, t}\right. \text {, }
$$


where the dependent variable is the natural log transformation of the foreign trading volume share as defined in equation (1), $X_{j, i, n, t}$ is a vector of explanatory variables representing the potential determinants and control variables, identified in the previous section, of the trading volume distribution of stock $i$ traded on foreign exchange $n$ during the month $t$. Since the dependent variable, the foreign trading volume share, is bounded between zero and one, we use the logistic transformation to transform a bounded variable into a continuous variable. All estimations include year fixed effects, and the standard errors are adjusted for heteroskedasticity using White's (1980) procedure and are adjusted to account for possible correlation within a cluster (also called Rogers standard errors) at the stock level. ${ }^{10}$

Table IV reports the coefficient estimates of equation (2) for the full sample (all host markets) (model 1) and for sub-samples of host markets: American host markets (model 2) and European host markets (model 3). The estimates show that most of the variables that represent the fundamental and informational motives of trading are statistically significant with theoretically plausible signs. ${ }^{11}$

\section{[Insert Table IV about here]}

Among the fundamental motives of trading, foreign trading volume share is anticipated to be positively associated with the diversification benefit of trading on crosslisted stocks; however, empirically this relationship holds only for US cross-listings (model 2). Thus, consistent with the findings of Halling et al. (2008) and in line with Hypothesis 1, stocks that exhibit a low return correlation with the US equity market returns (stocks with greater diversification benefit) appeal to foreign investors. An increase in one standard deviation of return correlation explains $20.8 \%$ of the standard deviation of the foreign trading activity in the US, all else being equal. ${ }^{12}$ The results also show that for European host market listings (model 3) direct trading cost is a significant determinant of foreign trading activity markets with lower trading costs attract more trading. This finding suggests that European

\footnotetext{
${ }^{10}$ Petersen (2009) suggests that this procedure accounts for potential biases in the estimates of standard errors when the residuals are correlated across stocks.

${ }^{11}$ We also computed variance inflation factors (VIFs) for the regressions reported in Table IV to check whether the results are affected by possible multicollinearity. VIFs (available upon request) show that the results are not affected by multicollinearity.

${ }^{12}$ Similarly to Bris, Cantale and Nishiotis (2007), we estimate the economic significance of each statistically significant variable as the product of the coefficient estimate with the standard deviation of the explanatory variable deflated by the standard deviation of the dependent variable. Economic significance indicates that the percentage of standard deviations of the dependent variable is explained by a one standard deviation change in the explanatory variable, keeping all else equal.
} 
investors are concerned about trading costs, perhaps due to the fact that other motives of trading, particularly informational, have become less relevant due to an ongoing effort by all European Union countries to improve disclosure and governance regimes. Economically, an increase in one standard deviation of trading cost difference explains $15.4 \%$ of the standard deviation of the foreign trading activity in European host markets, all else being equal. A theoretically consistent effect also appears for indirect trading costs. In particular, the results show that foreign listings in larger and more liquid markets generate a significantly higher trading share in the foreign market. The increase in liquidity is important for both American and European host markets while the difference in market size is significant for European host markets but not for American ones. Among the variables that capture trading costs, differences in market size relative to the home market have the strongest influence on the distribution of foreign trading volume. All else being equal, an increase by one standard deviation of the difference in market size explains $22.6 \%$ and $20.0 \%$ of the standard deviation of the foreign trading volume share for the full sample and European host markets respectively. Trading in the same currency occurs only in European host markets while trading in American host markets occurs exclusively in US dollars. Stocks that trade in foreign and domestic markets using the same currency exhibit more active trading in foreign markets. Overall, the empirical findings support Hypothesis 2 that lower costs of trading are associated with higher foreign trading volume share. Further results suggest that higher risk stocks demonstrate a higher share of foreign trading volume. Stock risk is a significant determinant of trading activity in American host markets, supportive of Hypothesis 3, but not in European host markets. An increase in stock risk by one standard deviation explains 7.9\% and $24.9 \%$ of the standard deviation of the foreign trading activity for the full sample and the American host markets’ sub-sample respectively.

The estimates also provide strong support to the informational motives of trading that arise from differences in the cost of acquiring information in host markets relative to that of the home market. The differences in legal environment are insignificant in explaining the trading volume distribution for the full sample. For the European host markets' sub-sample, the difference in investor protection is a negative and significant factor, implying that crosslisted stocks are more appealing to traders in the foreign market when they originate from a country with stronger investor protection than that in the foreign market. Therefore, there is no empirical evidence to support Hypothesis 4 that markets with a stronger legal environment attract more active trading of cross-listed stocks. Among informational factors, geographic 
proximity is the strongest determinant of the distribution of foreign trading volume - greater geographic distance is associated with lower foreign trading volume share. An increase in geographic distance by one standard deviation explains $63.1 \%$ of the standard deviation of the foreign trading activity. Geographic distance is particularly significant for European host markets. International accounting standards is a significant positive factor and analyst coverage is a significant negative factor for both American and European host markets. In addition, the foreign trading volume share of a European host market is positively related to common language and duration of listing, while the foreign trading volume share of an American host market is positively related to foreign sales. The finding that foreign trading increases over time differs from the evidence of Halling et al. (2008), who report that the US trading volume of non-US cross-listed stocks migrates back to the home market one or two years after the cross-listing. Our distinct findings on multi-market trading in various foreign markets (not just the US market) indicate that there may be differences in foreign trading volume trends between the US and non-US host markets. ${ }^{13}$ Our findings, consistent with the findings of Coval and Moskowitz (1999) and Grinblatt and Keloharju (2001), suggest that the level of trading activity in a foreign stock market relates to foreign investors' familiarity with the company and, consistent with Chordia et al. (2007) and Pulatkonak and Sofianos (1999), also relates to company visibility. Overall, we find empirical support for Hypothesis 5 that lower costs of acquiring information in a foreign market are associated with a higher share of trading in the foreign market. Finally, the effect of the foreign information factor articulated by Baruch et al. (2007) (Hypothesis 6) is significant in explaining the distribution of trading volume only for American host markets.

Among the control variables, the results indicate that 'Host US' dummy is positive and significant (model 1). This indicates that the US markets have a significant advantage in attracting trading of European stocks even after controlling for differences in fundamental and informational factors. Firm size is a positive significant factor for American host markets and a negative significant factor for European host markets, suggesting that stocks of larger foreign firms are traded more actively in American markets while stocks of smaller foreign firms are traded more actively in European host markets. Finally, for European host markets,

\footnotetext{
${ }^{13}$ We additionally test whether the fraction of foreign trading volume is significantly higher in the first years of cross-listing and re-estimate our model with two additional dummy variables that represent the first and second year after the cross-listing. The estimation results (not reported) show that the foreign trading volume share is not significantly different in the first and second years after the cross-listing, both for American and European cross-listings.
} 
when a stock is listed in multiple foreign markets, the share of trading of each of the foreign markets is smaller.

\section{Robustness test: Median regression}

Summary statistics of the 'foreign trading volume share' in Table III show that the mean (11.4\% for all host markets) and median (1.8\% for all host markets) values of this variable are noticeably different, implying the presence of extreme values (outliers) in the data set. Therefore, there might be a possibility that the OLS estimation results are affected by outliers. To address this concern, we estimate median regression that is more robust to outliers than least squares regression, for all the host markets and for American and European host markets' sub-samples. ${ }^{14}$ Table $\mathrm{V}$ reports the results. All variables that are significant in the OLS estimation (Table IV) are also significant in median regression estimation (Table V) with the same signs and same relative importance for American vs. European host markets. More specifically, market size and market liquidity have a positive effect, while the geographic distance between the home and host markets and financial analyst coverage have a negative effect on trading activities in all foreign host markets. Among the fundamental factors, diversification benefit and stock risk are positively related to the share of trading in American host markets while the direct trading costs and differences in currencies between the home and host markets reduce the share of trading in European host markets. Among informational factors, use of accounting standards and longer duration of listing in the foreign market are associated with higher share of trading in the foreign markets. Furthermore, foreign sales (trade) and the stock's foreign information factor positively affect the trading of cross-listed stocks in American host markets. On the other hand, common language between the home and host markets positively affects the trading of cross-listed stocks in European markets. Overall, the evidence shows that the OLS estimates are not affected by outliers.

\section{[Insert Table V about here]}

\subsection{Analysis by Host Market}

\footnotetext{
${ }^{14}$ As an additional robustness test, we estimate OLS regressions with winsorised explanatory variables. The results (available upon request) remain qualitatively similar, suggesting that the estimates reported in Table IV are not affected by outliers.
} 
In this section, we examine whether the relevance of the determinants of the foreign trading volume share varies across individual host markets. Accordingly, we re-estimate equation (2) separately for each of the host markets. Table VI reports the estimates for American host markets and Table VII for European host markets.

\section{US host markets}

American host markets in the sample include the NYSE and Nasdaq. Estimation results reported in Table VI suggest that these two markets have common determinants of trading activity in cross-listed stocks. Among the fundamental motives of trading, higher stock risk is a significant determinant both for the NYSE and Nasdaq. Greater diversification benefits and the increase in market liquidity are, however, significant factors for traders in the NYSE but not in Nasdaq. Among the informational motives of trading, foreign sales, international accounting standards, and foreign (US) information factor are significant positive determinants and analyst coverage is a significant negative determinant of trading both on the NYSE and Nasdaq. Duration of listing is a significant positive determinant of the foreign trading volume share only for the NYSE.

[Insert Table VI about here]

\section{European host markets}

European host markets in the sample include Amsterdam, Frankfurt, London, Paris and Swiss stock exchanges. Estimation results reported in Table VII suggest that these markets have several common determinants of trading activity in cross-listed stocks. In particular, the increase in market liquidity has a significant positive effect while geographic distance has a significant negative effect on the trading share of cross-listed stocks in European markets. In addition, the reduction in direct trading costs is associated with more active trading in Amsterdam and Paris. Riskier stocks trade more actively in Frankfurt, Paris and Swiss stock exchanges, stocks of smaller firms are traded more in Amsterdam and Frankfurt, and stocks of larger firms are traded more in Paris. Trading of foreign stocks in Amsterdam, London and Paris is less active when the stock is cross-listed in more than one foreign market.

[Insert Table VII about here] 
To summarize, there are differences in factors that determine the level of trading activity of cross-listed stocks in American and European host markets. Among the fundamental motives to trade, in addition to the increase in market liquidity, the common significant positive factor for all host markets, greater diversification benefits and higher stock risks are significant factors for American host markets. However, the reduction in trading cost and the same currency of trading are significant factors for European host markets. Among informational motives to trade, greater analyst coverage has an inverse effect and accounting standards have a positive effect on trading in all host markets. In addition, foreign sales and foreign information factor are significant positive determinants of trading in American host markets, while common language and duration of listing are significant positive determinants, and the difference in investor protection and geographic distance are significant negative determinants of trading in European host markets.

\section{CONCLUSIONS AND IMPLICATIONS}

The study examines and identifies the determinants of the distribution of foreign trading volume of European stocks listed in multiple markets - home and foreign stock exchanges. Based on the theoretical models of multi-market trading, a foreign host markets' share of trading is modeled as a function of factors representing company and market fundamentals as well as informational motives of trading. The study also distinguishes between the determinants of trading in American and European foreign host markets.

The findings of this study highlight the significance of the fundamental motives of trading, including improved market liquidity (measured by the differences in market size and liquidity between the foreign market and the home market) and stock risk, and of the informational motives of trading, including greater stock familiarity and visibility to foreign investors, (measured by geographic distance between the home and foreign market, accounting standards used by the cross-listed firms, the intensity of financial analyst coverage and the duration of listing on the foreign market). These findings confirm the theoretical predictions of Pagano (1989) and Domowitz et al. (1998) that in a multi-market setting trading location is determined by market liquidity and the quality of information environment. Furthermore, the findings reveal that American host markets, on average, attract a higher proportion of trading volume of European cross-listed stocks compared to European host markets (19.2\% vs. 5.8\% average 'foreign trading volume share’ respectively). We also find some differences in the determinants of the ability of various host markets to 
attract foreign equity trading. In particular, greater diversification benefits and higher stock risk are important considerations for traders in the US, while the reduction in trading costs and the same currency of trading are important considerations for traders in Europe. Furthermore, foreign sales (exports) and foreign information factor are significant positive determinants of trading activity in American host markets but insignificant in European host markets.

The findings have three important practical implications. First, for corporate managers seeking to improve their firm's stock liquidity through cross-listing in a foreign market, the results help identify the foreign market and the features that are most conducive to maximizing the stock's liquidity. This is reflected in the roles of the fundamental motives of trading, such as diversification benefits and trading costs, and the informational motives of trading, such as costs of acquiring information and a firm's familiarity and visibility in the foreign market. Second, for stock exchange executives and regulators, the results show how they could structure their stock exchanges in order to attract listings of foreign firms and enhance trading volume. In particular, the findings highlight the role of diversification benefits, costs of trading and the quality of the information environment in American and European markets. Finally, the results help investors/arbitrageurs in identifying the markets that are more liquid and safe in order to trade the stocks of foreign firms. 


\section{References}

Abdallah, A. A., W. Abdallah, and M. Saad (2011). The Effect of Cross-listing on Trading Volume: Reducing Segmentation versus Signaling Investor Protection. Journal of Financial Research, 34 (4), 589-616.

Abdallah, W. and M. Goergen (2008). Does Corporate Control Determine the Cross-listing Location? Journal of Corporate Finance, 14 (3), 183-199.

Anderson, A. M. and E. A. Dyl (2005). Market structure and trading volume. Journal of Financial Research, 28 (1), 115-131.

Aggarwal, R. (2002). Demutualization and Corporate Governance of Stock Exchanges. Journal of Applied Corporate Finance, 15 (1), 105-113.

Aggarwal, R., L. Klapper and P. D. Wysocki (2005). Portfolio Preferences of Foreign Institutional Investors. Journal of Banking and Finance, 29 (12), 2919-2946.

Ball, R. (2006). International Financial Reporting Standards (IFRS): Pros and Cons for Investors. Accounting and Business Research, 36 (Supplement 1), 5-27.

Bancel, F. and C. R. Mittoo (2001). European Managerial Perceptions of the Net Benefits of Foreign Stock Listings. European Financial Management, 7 (2), 213-236.

Bank of New York (2011). The Depositary Receipt Market 2011 Yearbook. Retrieved from http://www.adrbnymellon.com/dr_pub_statistics.jsp.

Baruch, S., G. A. Karolyi and M. Lemmon (2007). Multi-Market Trading and Liquidity: Theory and Evidence. The Journal of Finance, 62 (5), 2169-2200.

Bhattacharya, U. and H. Daouk (2002). The World Price of Insider Trading. The Journal of Finance, 57 (1), 75-108.

Brennan, M. and P. Hughes (1991). Stock Prices and the Supply of Information. The Journal of Finance, 46 (5), 1665-1691.

Bris, A., S. Cantale and G. P. Nishiotis (2007). A Breakdown of the Valuation Effects of International Cross-Listing. European Financial Management, 13 (3), 498-530.

Capstaff, J., K. Paudyal and W. Rees (2001). A Comparative Analysis of Earnings Forecasts in Europe. Journal of Business Finance and Accounting, 28 (5-6), 531-562.

Chiyachantana, C. N., P. K. Jain, C. X. Jiang and R. A. Wood (2004). International Evidence on Institutional Trading Behavior and Price Impact. The Journal of Finance, 59 (2), 869-898.

Chordia, T., S. W. Huh, and A. Subrahmanyam (2007). The Cross-Section of Expected Trading Activity. Review of Financial Studies, 20(3), 709-740.

Chowdhry, B. and V. Nanda (1991). Multimarket Trading and Market Liquidity. Review of Financial Studies, 4 (3), 483-511.

Coval, J. and T. Moskowitz (1999). Home Bias at Home: Local Equity Preference in Domestic Portfolios. Journal of Finance, 54, 2045-2073. 
Doidge, C., G. A. Karolyi and R. M. Stulz (2004). Why Are Foreign Firms Listed in the U.S. Worth More? Journal of Financial Economics, 71 (2), 205-238.

Domowitz, I., J. Glen and A. Madhavan (1998). International Cross-Listing and Order Flow Migration: Evidence from an Emerging Market. The Journal of Finance, 53 (6), 2001-2027.

Draper, P. and K. Paudyal (2008). Information Asymmetry and Bidders' Gains. Journal of Business Finance and Accounting, 35 (3-4), 376-405.

Durnev, A. A. and A. S. Nain (2007). Does Insider Trading Regulation Deter Private Information Trading? International Evidence. Pacific-Basin Finance Journal, 15 (5), 409433.

Fernandes, N. and M. A. Ferreira (2009). Insider Trading Laws and Stock Price Informativeness. Review of Financial Studies, 22 (5), 1845-1887.

Fernandes, N., and M. Giannetti, (2014). On the Fortunes of Stock Exchanges and Their Reversals: Evidence from Foreign Listings. Journal of Financial Intermediation, 23 (2), 157-176.

Fischer, P. E. (1992). Optimal Contracting and Insider Trading Restrictions. The Journal of Finance, 47 (2), 673-694.

Foerster, S. R. and G. A. Karolyi (1998). Multimarket Trading and Liquidity: A Transaction Data Analysis of Canada-US Inter-Listings. Journal of International Financial Markets, Institutions and Money, 8 (3-4), 393-412.

Gagnon, L. and G. A. Karolyi (2010). Do international cross-listings still matter? in Evidence on Financial Globalization and Crises, Thorsten Beck, Sergio Schmukler, and Stijn Claessens (Editors), Elsevier North-Holland Publishers.

Grinblatt, M. and M. Keloharju (2001). How Distance, Language, and Culture Influence Stockholdings and Trades. The Journal of Finance, 57 (3), 1053-1073.

Halling, M., M. Pagano, O. Randl and J. Zechner (2008). Where is the Market? Evidence from Cross-Listings in the US. The Review of Financial Studies, 21 (2), 725-761.

Huddart, S., J. S. Hughes and M. K. Brunnermeier (1999). Disclosure Requirements and Stock Exchange Listing Choice in an International Context. Journal of Accounting and Economics, 26 (1-3), 237-269.

Karolyi, G. A. (2012). Corporate Governance, Agency Problems and International Cross-listings: A Defense of the Bonding Hypothesis. Emerging Markets Review, 13 (4), 516-547.

La Porta, R., F. Lopez-de-Silanes and A. Shleifer. (2006). What works in securities laws? The Journal of Finance, 61 (1), 1-32.

Madhavan, A. (1995). Consolidation, Fragmentation, and the Disclosure of Trading Information. Review of Financial Studies, 8 (3), 579-603.

Maug, E. (2002). Insider Trading Legislation and Corporate Governance. European Economic Review, 46 (9), 1569-1597. 
Menyah, K. and K. Paudyal (2000). The Components of Bid-Ask Spreads on the London Stock Exchange. Journal of Banking and Finance, 24 (11), 1767-1785.

Pagano, M. (1989).Trading Volume and Asset Liquidity. Quarterly Journal of Economics,104 (2), 255-274.

Petersen, M. A. (2009). Estimating Standard Errors in Finance Panel Data Sets: Comparing Approaches. Review of Financial Studies, 22 (1), 435-480.

Pirinsky, C. and Q. Wang (2006). Does corporate headquarters location matter for stock returns? The Journal of Finance, 61 (4), 1991-2015.

Pulatkonak, M. and G. Sofianos (1999). The Distribution of Global Trading in NYSE-Listed Non-US Stocks. NYSE Working paper 99-03.

Reese, W. A. and M. S. Weisbach (2002). Protection of Minority Shareholder Interests, CrossListings in the United States, and Subsequent Equity Offerings. Journal of Financial Economics, 66 (1), 65-104.

Sarkissian, S. and M. J. Schill (2004). The Overseas Listing Decision: New Evidence of Proximity Preference. Review of Financial Studies, 17 (3), 769-809.

Shleifer, A. and R. W. Vishny (1997). A Survey of Corporate Governance. The Journal of Finance, 52 (2), 737-783.

Siegel, J. (2005). Can Foreign Firms Bond Themselves Effectively by Renting U.S. Securities Laws? Journal of Financial Economics, 75: 319-359.

Soderstrom, N. S. and K. J. Sun (2007). IFRS Adoption and Accounting Quality: A Review. European Accounting Review, 16 (4), 675-702.

Solnik, B. (1974). Why not diversify Internationally rather than Domestically? Financial Analysts Journal, 30 (4), 48-54.

White, H. (1980). A Heteroskedasticity-Consistent Covariance Matrix Estimator and a Direct Test for Heteroskedasticity. Econometrica, 48 (4), 817-838. 
Figure I. Foreign trading volume share in the five years after cross-listing

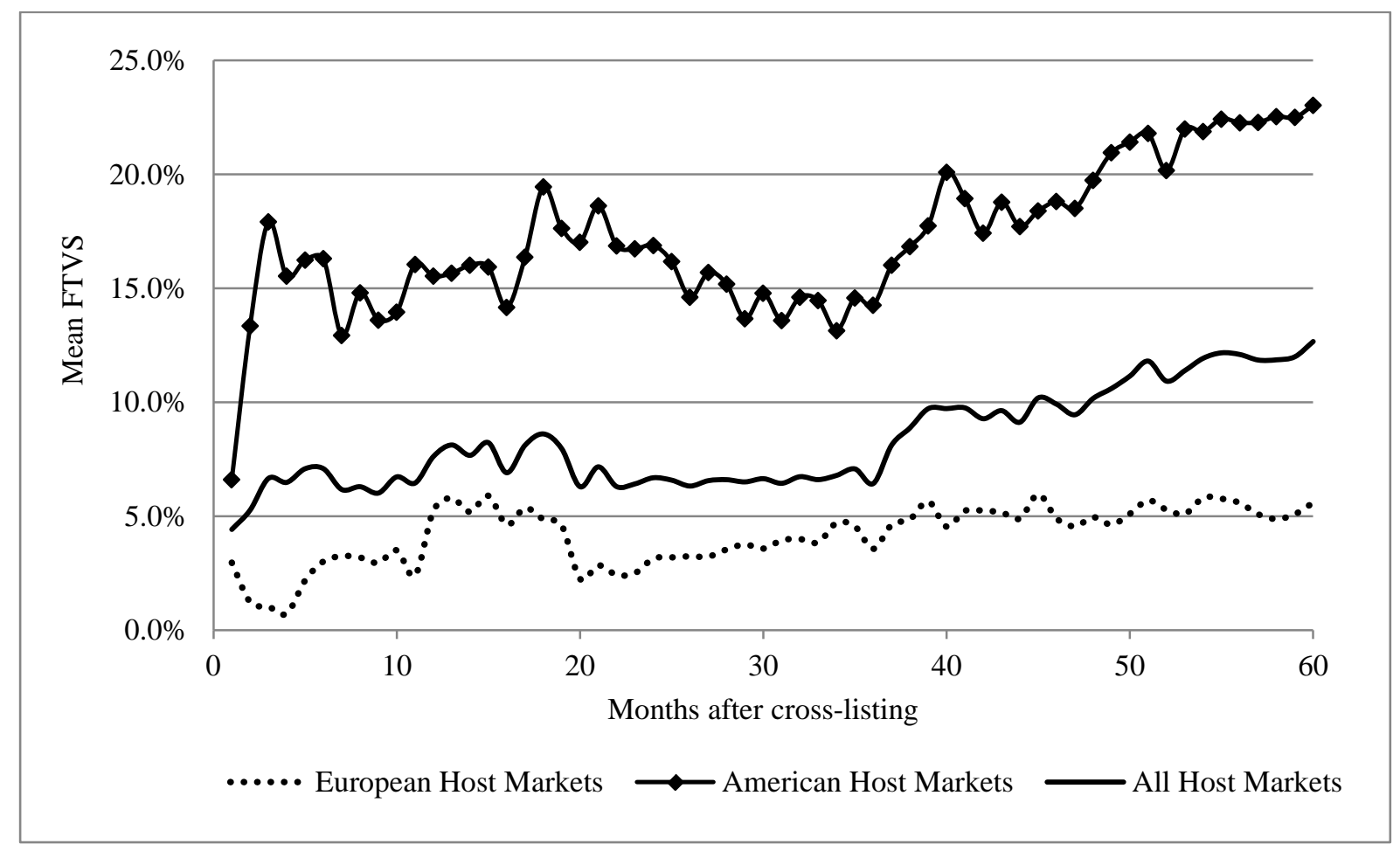

The figure presents the monthly average foreign trading volume share during the five years after cross-listing for the full sample and American and European host markets sub-samples. Foreign trading volume share is calculated as the ratio of the number of shares traded in a foreign market divided by the total number of the shares traded in the same month in all markets in the sample, including the stock's home market and foreign markets where the stock is listed. When trading on a foreign stock exchange takes place in the form of a DR, the number of traded shares is adjusted using the DR conversion ratio. Trading volume in Nasdaq and the LSE, the dealer markets in the sample, is adjusted for potential double counting of trading volume (Abdallah et al. (2011); Anderson and Dyl, 2005). 
Table I. Potential determinants of the foreign trading distribution

\begin{tabular}{llll}
\hline \hline \multicolumn{1}{c}{ Motives for trading } & Empirical measure & Variable level & Predicted sign \\
\hline $\begin{array}{l}\text { Fundamental factors } \\
\text { Diversification }\end{array}$ & Return correlation & Stock level & - \\
Direct trading cost & Trading cost difference & Market level & - \\
Indirect trading costs & & Stock level & + \\
Price per share & Price per share & Market level & + \\
Market size & Market size difference & Market level & + \\
Market liquidity & Market turnover difference & Stock level & + \\
Currency of trading & Same currency indicator & Stock level & + \\
Stock risk & Std. deviation of stock return & & \\
& & Market level & + \\
Informational factors & & Market level & + \\
Legal environment & Investor protection difference & Market level & + \\
Legal environment & Enforced insider trading laws difference & Market level & - \\
Cost of acquiring information & Common language & Stock level \\
Cost of acquiring information & Geographic distance & Stock level & + \\
Cost of acquiring information & Foreign sales & Stock level & + \\
Cost of acquiring information & Accounting standards & Stock level & - \\
Cost of acquiring information & Analyst coverage & Stock level \\
Cost of acquiring information & Analyst forecast error & Stock level \\
Cost of acquiring information & Duration of listing & + \\
Foreign information factor & Foreign information factor & + \\
\hline \hline
\end{tabular}

The table presents a list of potential determinants of the foreign trading distribution, proxy empirical measures of each of the determinants, and the sign of the predicted impact on the dependent variable (the foreign trading volume share): ‘+’ positive or '-’ negative. See Appendix A for the definition and data sources of the variables. 
Table II. The distribution of cross-listed firms by home and host markets

\begin{tabular}{|c|c|c|c|c|c|c|c|c|c|c|c|c|}
\hline \multirow[b]{3}{*}{ Home country } & \multicolumn{2}{|c|}{$\mathbf{N}$ firms } & \multicolumn{10}{|c|}{ Number of foreign listings } \\
\hline & \multirow[b]{2}{*}{$\mathbf{N}$ firms } & \multirow[b]{2}{*}{$\%$ of total } & \multicolumn{10}{|c|}{ Host markets } \\
\hline & & & All & American & European & NYSE & Nasdaq & Amsterdam & Frankfurt & London & Paris & Swiss \\
\hline Austria & 4 & 1.6 & 4 & & 4 & & & & 3 & & 1 & \\
\hline Belgium & 6 & 2.4 & 8 & 1 & 7 & 1 & & 2 & 2 & & 3 & \\
\hline Finland & 3 & 1.2 & 7 & 1 & 6 & 1 & & 2 & & 1 & 1 & 2 \\
\hline France & 26 & 10.2 & 44 & 13 & 31 & 11 & 2 & 10 & 9 & 8 & & 4 \\
\hline Germany & 33 & 13.0 & 68 & 12 & 56 & 8 & 4 & 11 & & 10 & 14 & 21 \\
\hline Greece & 3 & 1.2 & 5 & 3 & 2 & 3 & & & & 2 & & \\
\hline Ireland & 39 & 15.3 & 47 & 8 & 39 & 4 & 4 & & & 39 & & \\
\hline Italy & 10 & 3.9 & 14 & 4 & 10 & 4 & & 2 & 4 & & 4 & \\
\hline Netherlands & 27 & 10.6 & 49 & 10 & 39 & 7 & 3 & & 9 & 7 & 14 & 9 \\
\hline Norway & 5 & 2.0 & 9 & 2 & 7 & 1 & 1 & & 1 & 4 & 1 & 1 \\
\hline Portugal & 1 & 0.4 & 1 & 1 & & 1 & & & & & & \\
\hline Spain & 7 & 2.8 & 15 & 3 & 12 & 3 & & 4 & 2 & 3 & 3 & \\
\hline Sweden & 16 & 6.3 & 24 & 6 & 18 & 1 & 5 & 1 & 2 & 9 & 3 & 3 \\
\hline Switzerland & 12 & 4.7 & 17 & 7 & 10 & 6 & 1 & 1 & 5 & 2 & 2 & \\
\hline United Kingdom & 62 & 24.4 & 76 & 42 & 34 & 30 & 12 & 8 & 6 & & 17 & 3 \\
\hline Total & 254 & 100 & 388 & 113 & 275 & 81 & 32 & 41 & 43 & 85 & 63 & 43 \\
\hline
\end{tabular}

The table reports the distribution of the sample firms by their home country and foreign listings by host foreign markets. The sample includes 254 firms from 15 European countries with 388 foreign listings on seven major international stock exchanges. 
Table III. Summary statistics of variables of interest

\begin{tabular}{|c|c|c|c|c|c|c|c|c|c|c|c|c|c|c|c|}
\hline \multirow[b]{2}{*}{ Variables } & \multicolumn{5}{|c|}{ Full sample } & \multicolumn{3}{|c|}{ Host markets } & \multirow[b]{2}{*}{ NYSE } & \multirow[b]{2}{*}{ Nasdaq } & \multirow[b]{2}{*}{ Amsterdam } & \multirow[b]{2}{*}{ Frankfurt } & \multirow[b]{2}{*}{ London } & \multirow[b]{2}{*}{ Paris } & \multirow[b]{2}{*}{ Swiss } \\
\hline & Mean & Median & Min & Max & $\begin{array}{c}\text { St. } \\
\text { Dev. }\end{array}$ & American & European & $\begin{array}{l}\text { Diff. in } \\
\text { means }\end{array}$ & & & & & & & \\
\hline \multicolumn{16}{|l|}{ Panel A. Dependent variable } \\
\hline $\begin{array}{l}\text { FTVS, \% } \\
\text { FTVS mean, \% } \\
\text { FTVS median, \% }\end{array}$ & 11.4 & 1.8 & 0 & 100.0 & 21.2 & $\begin{array}{c}19.2 \\
8.9\end{array}$ & $\begin{array}{l}5.8 \\
0.2\end{array}$ & $13.4^{* * *}$ & $\begin{array}{c}18.1 \\
8.4\end{array}$ & $\begin{array}{l}22.8 \\
10.7\end{array}$ & $\begin{array}{c}11.4 \\
0.1\end{array}$ & $\begin{array}{l}0.8 \\
0.1\end{array}$ & $\begin{array}{c}12.7 \\
3.8\end{array}$ & $\begin{array}{l}2.4 \\
0.1\end{array}$ & $\begin{array}{l}1.9 \\
0.3\end{array}$ \\
\hline \multicolumn{16}{|l|}{$\begin{array}{l}\text { Panel B. Determinants } \\
\text { Fundamental factors }\end{array}$} \\
\hline Return correlation & 0.42 & 0.42 & -0.37 & 0.94 & 0.20 & 0.38 & 0.45 & $-0.07 * * *$ & 0.40 & 0.33 & 0.57 & 0.48 & 0.37 & 0.45 & 0.51 \\
\hline Trading cost difference & -0.03 & 0.03 & -0.62 & 0.47 & 0.20 & 0.04 & -0.08 & $0.12 * * *$ & 0.05 & 0.01 & -0.08 & 0.00 & -0.27 & -0.04 & 0.39 \\
\hline Price per share (GBP) & 20.04 & 12.40 & 0.03 & 1304 & 44.06 & 17.46 & 21.90 & $-4.44 * * *$ & 19.10 & 11.91 & 23.39 & 17.01 & 24.58 & 21.34 & 32.05 \\
\hline Market size difference & 14.83 & 4.37 & 0.17 & 293.9 & 30.69 & 25.98 & 6.76 & $19.22 * * *$ & 23.53 & 34.23 & 0.68 & 3.06 & 19.57 & 2.40 & 1.20 \\
\hline Market turnover difference & 6.27 & 1.37 & 0.01 & 109.8 & 14.54 & 5.47 & 6.84 & $-1.37 * * *$ & 5.36 & 5.83 & 12.92 & 0.32 & 9.75 & 5.28 & 18.46 \\
\hline Same currency indicator & 0.37 & 0.00 & 0.00 & 1.00 & 0.48 & 0.00 & 0.63 & $-0.63 * * *$ & 0.00 & 0.00 & 0.80 & 0.74 & 0.55 & 0.65 & 0.00 \\
\hline $\begin{array}{l}\text { Stock risk } \\
\quad \text { Informational factors }\end{array}$ & 0.05 & 0.04 & 0.00 & 0.26 & 0.03 & 0.05 & 0.05 & $0.004 * * *$ & 0.04 & 0.06 & 0.05 & 0.04 & 0.05 & 0.04 & 0.03 \\
\hline $\begin{array}{l}\text { Investor protection difference } \\
\text { Enforced insider trading laws }\end{array}$ & 0.21 & 0.24 & -0.78 & 1.00 & 0.39 & 0.45 & 0.03 & $0.42 * * *$ & 0.45 & 0.46 & 0.23 & -0.45 & 0.38 & 0.03 & 0.03 \\
\hline difference & 0.15 & 0.00 & 0.00 & 1.00 & 0.35 & 0.09 & 0.19 & $-0.10 * * *$ & 0.08 & 0.13 & 0.00 & 0.06 & 0.58 & 0.07 & 0.00 \\
\hline Common language & 0.33 & 0.00 & 0.00 & 1.00 & 0.47 & 0.48 & 0.23 & $0.25 * * *$ & 0.46 & 0.53 & 0.00 & 0.15 & 0.58 & 0.05 & 0.49 \\
\hline Geographic distance, $x 10^{3} \mathrm{~km}$ & 2.90 & 1.07 & 0.17 & 8.26 & 2.79 & 6.15 & 0.55 & $5.60 * * *$ & 6.17 & 6.09 & 0.48 & 0.52 & 0.58 & 0.56 & 0.66 \\
\hline Foreign sales & 0.59 & 0.61 & 0.00 & 1.00 & 0.25 & 0.59 & 0.59 & 0.00 & 0.57 & 0.68 & 0.57 & 0.59 & 0.57 & 0.60 & 0.66 \\
\hline Accounting standards & 0.45 & 0.00 & 0.00 & 1.00 & 0.50 & 0.42 & 0.47 & $-0.05^{* * *}$ & 0.40 & 0.48 & 0.61 & 0.46 & 0.47 & 0.35 & 1.00 \\
\hline Analyst coverage & 18.93 & 19.00 & 0.00 & 55.00 & 10.82 & 18.97 & 18.90 & 0.07 & 20.93 & 12.35 & 20.30 & 19.46 & 13.27 & 21.65 & 24.60 \\
\hline Analyst forecast error & 1.32 & 0.19 & 0 & 747 & 20.85 & 0.89 & 1.64 & $-0.75 * * *$ & 0.44 & 2.42 & 2.36 & 0.63 & 1.85 & 2.17 & 0.34 \\
\hline Duration of listing & 7.46 & 6.42 & 0.17 & 22.00 & 4.81 & 8.78 & 6.51 & $2.26 * * *$ & 8.82 & 8.61 & 5.59 & 6.37 & 5.14 & 7.21 & 12.70 \\
\hline Foreign information factor & 2.54 & 1.48 & 0.00 & 162.0 & 5.68 & 2.28 & 2.73 & $-0.45 * * *$ & 2.19 & 2.58 & 3.24 & 4.55 & 1.48 & 2.29 & 1.96 \\
\hline Control variables & & & & & & & & & & & & & & & \\
\hline Company size (x10 mln GBP) & 17.19 & 8.60 & 0.00 & 158.5 & 22.57 & 17.52 & 16.95 & $0.57 * *$ & 21.49 & 4.12 & 24.89 & 16.03 & 9.35 & 19.71 & 23.34 \\
\hline Growth opportunities & 4.27 & 2.39 & & 553.4 & 17.23 & 5.36 & 3.48 & $1.88 * * *$ & 5.03 & 6.46 & 3.33 & 4.74 & 2.86 & 3.20 & 2.69 \\
\hline $\mathrm{N}$ foreign listings & 1.95 & 2.00 & 1.00 & 6.00 & 1.14 & 1.62 & 2.18 & $-0.56 * * *$ & 1.75 & 1.18 & 2.53 & 2.09 & 1.96 & 2.30 & 2.12 \\
\hline Host US & 0.34 & 0.00 & 0.00 & 1.00 & 0.47 & 1.00 & 0.00 & & & & & & & & \\
\hline $\mathrm{N}$ observations & & & 23,106 & & & 9,802 & 13,304 & & 7,575 & 2,227 & 1,665 & 3,326 & 3,354 & 4,327 & 632 \\
\hline
\end{tabular}

The table reports summary statistics of the foreign trading volume share (FTVS) and of the determinants of the foreign trading volume distribution for (i) the full sample of 254 companies with 388 foreign listings during 1990-2007, and (ii) sub-samples by host market. All variables are defined in Appendix A. Additionally the table reports the difference in means between the American host markets and European host markets; its statistical significance is based on the t-test of the difference in means. ${ }^{* * *}$ and $* *$ indicate significant at $1 \%$ and $5 \%$ respectively. 
Table IV. Determinants of foreign trading volume share

\begin{tabular}{|c|c|c|c|c|c|c|c|}
\hline \multirow[b]{2}{*}{ Variable } & \multirow[b]{2}{*}{$\begin{array}{l}\text { Exp. } \\
\text { sign }\end{array}$} & \multicolumn{2}{|c|}{ (1) All host markets } & \multicolumn{2}{|c|}{$\begin{array}{c}\text { (2) American host } \\
\text { markets }\end{array}$} & \multicolumn{2}{|c|}{$\begin{array}{c}\text { (3) European host } \\
\text { markets }\end{array}$} \\
\hline & & Estimate & $\begin{array}{c}\text { Econ } \\
\text { sig. } \% \\
\end{array}$ & Estimate & $\begin{array}{c}\text { Econ } \\
\text { sig. \% } \\
\end{array}$ & Estimate & $\begin{array}{r}\text { Econ } \\
\text { sig. \% }\end{array}$ \\
\hline \multicolumn{8}{|l|}{ Fundamental factors } \\
\hline Return correlation & - & $\begin{array}{c}0.08 \\
(0.13)\end{array}$ & & $\begin{array}{c}-2.65 * * * \\
(-3.67)\end{array}$ & $20.8 \%$ & $\begin{array}{l}1.48^{*} \\
(1.93)\end{array}$ & $9.8 \%$ \\
\hline Trading cost difference & - & $\begin{array}{c}-0.94 \\
(-1.28)\end{array}$ & & $\begin{array}{c}0.45 \\
(0.43)\end{array}$ & & $\begin{array}{c}-2.26 * * * \\
(-3.11)\end{array}$ & $15.4 \%$ \\
\hline Price per share & + & $\begin{array}{l}-0.12 \\
(-0.87)\end{array}$ & & $\begin{array}{c}0.22 \\
(1.17)\end{array}$ & & $\begin{array}{l}-0.12 \\
(-0.83)\end{array}$ & \\
\hline Market size difference & + & $\begin{array}{c}0.49 * * * \\
(2.92)\end{array}$ & $22.6 \%$ & $\begin{array}{c}0.05 \\
(0.20)\end{array}$ & & $\begin{array}{l}0.44^{* *} \\
(2.23)\end{array}$ & $20.0 \%$ \\
\hline Market turnover difference & + & $\begin{array}{c}0.40 * * * \\
(4.65)\end{array}$ & $21.8 \%$ & $\begin{array}{c}0.80 * * * \\
(4.93)\end{array}$ & $3.8 \%$ & $\begin{array}{c}0.48^{* * *} \\
(5.06)\end{array}$ & $33.6 \%$ \\
\hline Same currency indicator & + & $\begin{array}{c}0.41 \\
(1.27)\end{array}$ & & & & $\begin{array}{l}0.61^{*} \\
(1.86)\end{array}$ & $9.4 \%$ \\
\hline Stock risk & + & $\begin{array}{l}10.19 * \\
(1.90)\end{array}$ & $7.9 \%$ & $\begin{array}{c}18.97 * * * \\
(4.57)\end{array}$ & $24.9 \%$ & $\begin{array}{c}9.47 \\
(1.21)\end{array}$ & \\
\hline \multicolumn{8}{|l|}{ Informational factors } \\
\hline Investor protection difference & + & $\begin{array}{l}-0.89 \\
(-1.41)\end{array}$ & & $\begin{array}{c}0.68 \\
(0.55)\end{array}$ & & $\begin{array}{c}-2.15^{* * *} \\
(-3.11)\end{array}$ & $26.7 \%$ \\
\hline Enforced IT laws difference & + & $\begin{array}{l}0.37 \\
(0.62)\end{array}$ & & $\begin{array}{c}0.16 \\
(0.23)\end{array}$ & & $\begin{array}{c}-0.27 \\
(-0.36)\end{array}$ & \\
\hline Common language & + & $\begin{array}{c}0.45 \\
(1.25)\end{array}$ & & & & $\begin{array}{l}1.38 * * \\
(2.13)\end{array}$ & $18.3 \%$ \\
\hline Geographic distance & - & $\begin{array}{c}-1.58^{* * *} \\
(-5.09)\end{array}$ & $63.1 \%$ & $\begin{array}{l}-4.47 \\
(-1.48)\end{array}$ & & $\begin{array}{c}-1.47 * * * \\
(-4.58)\end{array}$ & $25.2 \%$ \\
\hline Foreign sales & + & $\begin{array}{c}0.57 \\
(1.31)\end{array}$ & & $\begin{array}{c}1.23^{* * *} \\
(2.80)\end{array}$ & $15.0 \%$ & $\begin{array}{c}0.02 \\
(0.04)\end{array}$ & \\
\hline Accounting standards & + & $\begin{array}{c}0.86^{* * *} \\
(3.49)\end{array}$ & $12.8 \%$ & $\begin{array}{c}0.86^{* * *} \\
(3.43)\end{array}$ & $20.4 \%$ & $\begin{array}{l}0.74 * * \\
(2.10)\end{array}$ & $11.8 \%$ \\
\hline Analyst coverage & - & $\begin{array}{c}-0.32 * * * \\
(-5.13)\end{array}$ & $12.4 \%$ & $\begin{array}{c}-0.46^{* * * *} \\
(-6.30)\end{array}$ & $34.0 \%$ & $\begin{array}{l}-0.25^{* *} \\
(-2.08)\end{array}$ & $8.7 \%$ \\
\hline Analyst forecast error & + & $\begin{array}{c}-0.00 \\
(-0.26)\end{array}$ & & $\begin{array}{l}0.00 \\
(0.11)\end{array}$ & & $\begin{array}{l}0.00 \\
(0.84)\end{array}$ & \\
\hline Duration of listing & + & $\begin{array}{l}0.05^{*} \\
(1.73)\end{array}$ & $7.2 \%$ & $\begin{array}{c}0.04 \\
(1.55)\end{array}$ & & $\begin{array}{l}0.08^{*} \\
(1.85)\end{array}$ & $10.9 \%$ \\
\hline Foreign information factor & + & $\begin{array}{c}0.01 \\
(0.97)\end{array}$ & & $\begin{array}{c}0.12 * * * \\
(3.19)\end{array}$ & $13.6 \%$ & $\begin{array}{l}-0.00 \\
(-0.23)\end{array}$ & \\
\hline \multicolumn{8}{|l|}{ Control variables } \\
\hline Company size & + & $\begin{array}{l}-0.07 \\
(-0.65)\end{array}$ & & $\begin{array}{l}0.27 * * \\
(2.58)\end{array}$ & $22.0 \%$ & $\begin{array}{l}-0.28 * \\
(-1.91)\end{array}$ & $17.0 \%$ \\
\hline Growth opportunities & + & $\begin{array}{c}0.00 \\
(0.63)\end{array}$ & & $\begin{array}{c}0.00 \\
(0.96)\end{array}$ & & $\begin{array}{c}0.00 \\
(0.32)\end{array}$ & \\
\hline $\mathrm{N}$ foreign listings & - & $\begin{array}{l}-0.23^{*} \\
(-1.71)\end{array}$ & $7.8 \%$ & $\begin{array}{c}0.18 \\
(1.65)\end{array}$ & & $\begin{array}{l}-0.35 * * \\
(-2.07)\end{array}$ & $13.4 \%$ \\
\hline Host US & + & $\begin{array}{l}7.17 * * * \\
(9.33)\end{array}$ & $106.2 \%$ & & & & \\
\hline Intercept & & $\begin{array}{c}4.46^{* *} \\
(2.12)\end{array}$ & & $\begin{array}{l}34.48 \\
(1.31)\end{array}$ & & $\begin{array}{c}4.51^{* *} \\
(2.06)\end{array}$ & \\
\hline Year-fixed effects & & YES & & YES & & YES & \\
\hline $\mathrm{N}$ of observations & & 23,106 & & 9,802 & & 13,304 & \\
\hline Adj. R-sq & & 0.56 & & 0.47 & & 0.43 & \\
\hline
\end{tabular}

The table reports the OLS estimates of equation (2): $\operatorname{Ln}\left(F_{T V S} S_{i, n, t} /\left(1-F T V S_{i, n, t}\right)=\gamma_{0}+\sum_{j=1}^{J} \gamma_{j} X_{j, i, n, t}+\varepsilon_{i, t}\right.$, where

$F T V S_{i, n, t}$ is the foreign trading volume share and the vector $X_{j, i, n, t}$ represents the determinants of the foreign trading volume distribution. All variables are defined in Appendix A. Output also includes the economic significance (econ. sig. \%) of the variables calculated as the product of the coefficient estimate and the variable's standard deviation divided by the standard deviation of the dependent variable. t-statistics (reported in parentheses) are heteroskedasticity consistent (White, 1980) and adjusted for clustering at the stock level. ${ }^{* * *}, * *$ and $*$ indicate significant at $1 \%, 5 \%$ and $10 \%$ respectively. 
Table V. Determinants of foreign trading volume share: Median regressions

\begin{tabular}{|c|c|c|c|c|}
\hline Variable & $\begin{array}{l}\text { Exp. } \\
\text { sign }\end{array}$ & $\begin{array}{l}\text { (1) All host } \\
\text { markets }\end{array}$ & $\begin{array}{c}\text { (2) American host } \\
\text { markets }\end{array}$ & $\begin{array}{c}\begin{array}{c}\text { (3) European host } \\
\text { markets }\end{array} \\
\end{array}$ \\
\hline \multicolumn{5}{|l|}{ Fundamental factors } \\
\hline Return correlation & - & $\begin{array}{c}-0.48 * * * \\
(-4.32)\end{array}$ & $\begin{array}{l}-2.56 * * * \\
(-18.24)\end{array}$ & $\begin{array}{c}0.94 * * * \\
(6.17)\end{array}$ \\
\hline Trading cost difference & - & $\begin{array}{c}-0.65 * * * \\
(-5.56)\end{array}$ & $\begin{array}{l}-0.03 \\
(-0.16)\end{array}$ & $\begin{array}{c}-1.55^{* * *} \\
(-8.59)\end{array}$ \\
\hline Price per share & + & $\begin{array}{l}-0.05^{*} \\
(-1.80)\end{array}$ & $\begin{array}{c}0.21^{* * *} \\
(6.76)\end{array}$ & $\begin{array}{c}0.01 \\
(0.20)\end{array}$ \\
\hline Market size difference & + & $\begin{array}{c}0.65^{* * *} \\
(21.13)\end{array}$ & $\begin{array}{c}-0.05 \\
(-1.24)\end{array}$ & $\begin{array}{c}0.56^{* * *} \\
(12.97)\end{array}$ \\
\hline Market turnover difference & + & $\begin{array}{c}0.37 * * * \\
(19.12)\end{array}$ & $\begin{array}{l}0.84 * * * \\
(27.77)\end{array}$ & $\begin{array}{l}0.52 * * * \\
(20.24)\end{array}$ \\
\hline Same currency indicator & + & $\begin{array}{c}0.43^{* * *} \\
(7.30)\end{array}$ & & $\begin{array}{c}0.58^{* * *} \\
(9.34)\end{array}$ \\
\hline Stock risk & + & $\begin{array}{c}12.34^{* * *} \\
(12.46)\end{array}$ & $\begin{array}{c}18.68 * * * \\
(19.35)\end{array}$ & $\begin{array}{c}8.89 * * * \\
(3.85)\end{array}$ \\
\hline \multicolumn{5}{|l|}{ Informational factors } \\
\hline Investor protection difference & + & $\begin{array}{c}-1.08 * * * \\
(-8.38)\end{array}$ & $\begin{array}{c}0.70^{* * *} \\
(3.50)\end{array}$ & $\begin{array}{l}-2.75 * * * \\
(-16.56)\end{array}$ \\
\hline Enforced IT laws difference & + & $\begin{array}{c}0.73 * * * \\
(6.23)\end{array}$ & $\begin{array}{c}0.04 \\
(0.24)\end{array}$ & $\begin{array}{c}0.20 \\
(1.34)\end{array}$ \\
\hline Common language & + & $\begin{array}{c}0.75^{* * *} \\
(13.49)\end{array}$ & & $\begin{array}{l}2.01 * * * \\
(22.06)\end{array}$ \\
\hline Geographic distance & - & $\begin{array}{l}-1.60 * * * \\
(-31.35)\end{array}$ & $\begin{array}{c}-3.53 * * * \\
(-6.42)\end{array}$ & $\begin{array}{l}-1.31 * * * \\
(-26.56)\end{array}$ \\
\hline Foreign sales & + & $\begin{array}{c}0.92 * * * \\
(14.12)\end{array}$ & $\begin{array}{l}1.45^{* * *} \\
(21.72)\end{array}$ & $\begin{array}{c}-0.27 * * * \\
(-2.59)\end{array}$ \\
\hline Accounting standards & + & $\begin{array}{c}0.96 * * * \\
(18.44)\end{array}$ & $\begin{array}{c}0.73 * * * \\
(13.05)\end{array}$ & $\begin{array}{c}0.84^{* * *} \\
(9.98)\end{array}$ \\
\hline Analyst coverage & - & $\begin{array}{l}-0.33 * * * \\
(-12.83)\end{array}$ & $\begin{array}{l}-0.42 * * * \\
(-23.36)\end{array}$ & $\begin{array}{c}-0.34 * * * \\
(-3.73)\end{array}$ \\
\hline Analyst forecast error & + & $\begin{array}{c}-0.00 \\
(-1.12)\end{array}$ & $\begin{array}{c}-0.00 \\
(-0.54)\end{array}$ & $\begin{array}{c}0.00 \\
(0.87)\end{array}$ \\
\hline Duration of listing & + & $\begin{array}{c}0.02 * * * \\
(5.15)\end{array}$ & $\begin{array}{c}0.05^{* * * *} \\
(13.58)\end{array}$ & $\begin{array}{c}0.03^{* * *} \\
(4.40)\end{array}$ \\
\hline Foreign information factor & + & $\begin{array}{c}0.004^{* * * *} \\
(4.49)\end{array}$ & $\begin{array}{l}0.12 * * * \\
(18.15)\end{array}$ & $\begin{array}{c}0.01 * * * \\
(4.65)\end{array}$ \\
\hline Control variables & & & & \\
\hline$\overline{\text { Company size }}$ & + & $\begin{array}{c}0.07 * * * \\
(4.00)\end{array}$ & $\begin{array}{c}0.28 * * * \\
(16.23)\end{array}$ & $\begin{array}{c}-0.13 * * * \\
(-3.93)\end{array}$ \\
\hline Growth opportunities & + & $\begin{array}{l}-0.00 \\
(-0.96)\end{array}$ & $\begin{array}{c}0.00 \\
(0.52)\end{array}$ & $\begin{array}{c}-0.002 * * * \\
(-2.96)\end{array}$ \\
\hline $\mathrm{N}$ foreign listings & - & $\begin{array}{c}-0.14 * * * \\
(-6.41)\end{array}$ & $\begin{array}{c}0.12^{* * *} \\
(6.87)\end{array}$ & $\begin{array}{c}-0.20 * * * \\
(-7.05)\end{array}$ \\
\hline Host US & + & $\begin{array}{c}7.09 * * * \\
(50.36)\end{array}$ & & \\
\hline Intercept & & $\begin{array}{c}2.73 * * * \\
(6.11)\end{array}$ & $\begin{array}{c}26.17 * * * \\
(5.38)\end{array}$ & $\begin{array}{c}2.31^{* * *} \\
(5.42)\end{array}$ \\
\hline Year-fixed effects & & YES & YES & YES \\
\hline $\mathrm{N}$ of observations & & 23,106 & 9,802 & 13,304 \\
\hline R-squared & & 0.54 & 0.46 & 0.41 \\
\hline
\end{tabular}

The table reports the median regression estimates of equation (2): $\operatorname{Ln}\left(F T V S_{i, n, t} /\left(1-F T V S_{i, n, t}\right)=\gamma_{0}+\sum_{j=1}^{J} \gamma_{j} X_{j, i, n, t}+\varepsilon_{i, t}\right.$, where $F T V S_{i, n, t}$ is the foreign trading volume share and the vector $X_{j, i, n, t}$ represents the determinants of the foreign trading volume distribution. All variables are defined in Appendix A. t-statistics (reported in parentheses) are calculated using standard errors that are asymptotically valid under heteroskedasticity and intracluster correlation. ***, ** and $*$ indicate significant at $1 \%, 5 \%$ and $10 \%$ respectively. 
Table VI. Determinants of the trading volume distribution: American host markets

\begin{tabular}{|c|c|c|c|}
\hline & Exp. sign & NYSE & Nasdaq \\
\hline \multicolumn{4}{|l|}{ Fundamental factors } \\
\hline Return correlation & - & $\begin{array}{c}-2.37 * * * \\
(-3.66)\end{array}$ & $\begin{array}{c}-2.41 \\
(-1.54)\end{array}$ \\
\hline Trading cost difference & - & $\begin{array}{c}0.95 \\
(0.93)\end{array}$ & $\begin{array}{c}-1.23 \\
(-0.72)\end{array}$ \\
\hline Price per share & + & $\begin{array}{c}0.20 \\
(1.10)\end{array}$ & $\begin{array}{l}0.34^{*} \\
(1.72)\end{array}$ \\
\hline Market size difference & + & $\begin{array}{c}0.07 \\
(0.30)\end{array}$ & $\begin{array}{c}-0.09 \\
(-0.30)\end{array}$ \\
\hline Market turnover difference & + & $\begin{array}{c}1.07^{* * *} \\
(6.92)\end{array}$ & $\begin{array}{c}-0.10 \\
(-0.33)\end{array}$ \\
\hline Stock risk & + & $\begin{array}{c}19.23^{* * *} \\
(3.56)\end{array}$ & $\begin{array}{c}15.98 * * * \\
(2.91)\end{array}$ \\
\hline \multicolumn{4}{|l|}{ Informational factors } \\
\hline Investor protection difference & + & $\begin{array}{c}0.33 \\
(0.27)\end{array}$ & $\begin{array}{c}2.73 \\
(1.23)\end{array}$ \\
\hline Enforced IT laws difference & + & $\begin{array}{c}-0.78 \\
(-1.14)\end{array}$ & $\begin{array}{c}0.39 \\
(0.14)\end{array}$ \\
\hline Geographic distance & - & $\begin{array}{c}-1.99 \\
(-0.70)\end{array}$ & $\begin{array}{l}-17.04 \\
(-1.25)\end{array}$ \\
\hline Foreign sales & + & $\begin{array}{c}1.09 * * * \\
(2.74)\end{array}$ & $\begin{array}{c}2.61^{* * * *} \\
(3.99)\end{array}$ \\
\hline Accounting standards & + & $\begin{array}{l}0.48^{*} \\
(1.93)\end{array}$ & $\begin{array}{c}1.58^{* * *} \\
(4.04)\end{array}$ \\
\hline Analyst coverage & - & $\begin{array}{c}-0.44 * * * \\
(-6.80)\end{array}$ & $\begin{array}{c}-0.26^{* *} \\
(-2.51)\end{array}$ \\
\hline Analyst forecast error & + & $\begin{array}{c}0.02 \\
(0.33)\end{array}$ & $\begin{array}{c}0.00 \\
(0.30)\end{array}$ \\
\hline Duration of listing & + & $\begin{array}{c}0.07 * * * \\
(3.41)\end{array}$ & $\begin{array}{c}-0.06 \\
(-1.22)\end{array}$ \\
\hline Foreign information factor & + & $\begin{array}{l}0.08^{*} \\
(1.83)\end{array}$ & $\begin{array}{c}0.15^{* * *} \\
(3.40)\end{array}$ \\
\hline Control variables & & & \\
\hline Company size & + & $\begin{array}{c}0.32 * * \\
(2.41)\end{array}$ & $\begin{array}{l}-0.09 \\
(-0.62)\end{array}$ \\
\hline Growth opportunities & + & $\begin{array}{c}0.01 \\
(0.85)\end{array}$ & $\begin{array}{c}0.01 * * \\
(2.70)\end{array}$ \\
\hline $\mathrm{N}$ foreign listings & - & $\begin{array}{c}0.09 \\
(0.83)\end{array}$ & $\begin{array}{l}1.02 * * \\
(2.57)\end{array}$ \\
\hline Intercept & & $\begin{array}{l}13.51 \\
(0.54)\end{array}$ & $\begin{array}{l}142.65 \\
(1.21)\end{array}$ \\
\hline Year-fixed effects & & YES & YES \\
\hline $\mathrm{N}$ of observations & & 7,575 & 2,227 \\
\hline Adj. R-sq & & 0.53 & 0.72 \\
\hline
\end{tabular}

The table reports the OLS estimates of equation (2) separately for the NYSE and Nasdaq host markets:

$\operatorname{Ln}\left(F T V S_{i, n, t} /\left(1-F T V S_{i, n, t}\right)=\gamma_{0}+\sum_{j=1}^{J} \gamma_{j} X_{j, i, n, t}+\varepsilon_{i, t}\right.$, where $F T V S_{i, n, t}$ is the foreign trading volume share and the vector $X_{j, i, n, t}$ represents the determinants of the foreign trading volume distribution. All variables are defined in Appendix A. t-statistics (reported in parentheses) are heteroskedasticity consistent (White, 1980) and adjusted for clustering at the stock level. $* * *, * *$ and $*$ indicate significant at $1 \%, 5 \%$ and $10 \%$ respectively. 
Table VII. Determinants of the trading volume distribution: European host markets

\begin{tabular}{|c|c|c|c|c|c|c|}
\hline & Exp. sign & Amsterdam & Frankfurt & London & Paris & "Swiss \\
\hline \multicolumn{7}{|l|}{ Fundamental factors } \\
\hline \multirow[t]{2}{*}{ Return correlation } & - & $2.81 *$ & 0.14 & 0.90 & 0.19 & 0.44 \\
\hline & & $(1.74)$ & $(0.15)$ & $(0.62)$ & $(0.18)$ & $(0.24)$ \\
\hline \multirow[t]{2}{*}{ Trading cost difference } & - & $-11.34^{* *}$ & 2.64 & -3.80 & $-4.41 * *$ & 17.78 \\
\hline & & $(-2.10)$ & $(0.31)$ & $(-1.46)$ & $(-2.12)$ & $(1.16)$ \\
\hline \multirow[t]{2}{*}{ Price per share } & + & 0.02 & -0.11 & $-0.63 * * *$ & -0.35 & 0.06 \\
\hline & & $(0.06)$ & $(-0.50)$ & $(-3.10)$ & $(-1.59)$ & $(0.24)$ \\
\hline \multirow[t]{2}{*}{ Market size difference } & + & $2.90 * * *$ & $-0.80 *$ & 0.82 & $1.12 * *$ & -1.40 \\
\hline & & $(4.21)$ & $(-1.99)$ & $(1.21)$ & $(2.51)$ & $(-1.20)$ \\
\hline \multirow[t]{2}{*}{ Market turnover difference } & + & 0.12 & $0.16^{* *}$ & 0.59 & $0.73^{* * *}$ & $1.40 * * *$ \\
\hline & & $(0.52)$ & $(2.37)$ & $(1.56)$ & $(4.43)$ & (3.09) \\
\hline \multirow[t]{2}{*}{ Same currency indicator } & + & $-2.34 *$ & 0.70 & 1.03 & 0.83 & \\
\hline & & $(-1.71)$ & $(0.81)$ & (1.36) & (1.23) & \\
\hline \multirow[t]{2}{*}{ Stock risk } & + & -0.75 & $17.11^{* *}$ & -5.24 & $22.06 * *$ & $32.42 *$ \\
\hline & & $(-0.09)$ & $(2.08)$ & $(-0.97)$ & $(2.46)$ & $(1.73)$ \\
\hline \multicolumn{7}{|l|}{ Informational factors } \\
\hline \multirow[t]{2}{*}{ Investor protection difference } & + & $-3.53^{* *}$ & -0.29 & 1.62 & 0.71 & 0.94 \\
\hline & & $(-2.06)$ & $(-0.20)$ & $(0.46)$ & $(0.51)$ & $(0.21)$ \\
\hline \multirow[t]{2}{*}{ Enforced IT laws difference } & + & & 1.81 & 2.70 & -0.61 & \\
\hline & & & $(1.24)$ & $(1.27)$ & $(-1.61)$ & \\
\hline \multirow[t]{2}{*}{ Common language } & + & & 2.26 & & -2.30 & \\
\hline & & & $(0.61)$ & & $(-1.55)$ & \\
\hline \multirow[t]{2}{*}{ Geographic distance } & - & $-3.86 * * *$ & $-0.89 * *$ & $-2.11 *$ & $-3.14 * * *$ & 3.48 \\
\hline & & $(-4.35)$ & $(-2.29)$ & $(-1.92)$ & $(-4.08)$ & $(1.31)$ \\
\hline \multirow[t]{2}{*}{ Foreign sales } & + & 0.12 & -0.12 & -0.56 & -0.10 & -1.24 \\
\hline & & $(0.11)$ & $(-0.14)$ & $(-0.63)$ & $(-0.12)$ & $(-1.67)$ \\
\hline \multirow[t]{2}{*}{ Accounting standards } & + & -0.64 & $1.07 * *$ & -0.10 & 0.36 & \\
\hline & & $(-1.42)$ & $(2.23)$ & $(-0.29)$ & $(0.79)$ & \\
\hline \multirow[t]{2}{*}{ Analyst coverage } & - & -0.12 & $-0.39 * *$ & 0.06 & 0.09 & $-0.22 * *$ \\
\hline & & $(-1.12)$ & $(-2.50)$ & $(0.49)$ & $(0.28)$ & $(-2.58)$ \\
\hline \multirow[t]{2}{*}{ Analyst forecast error } & + & 0.00 & -0.05 & $0.002 *$ & 0.00 & 0.19 \\
\hline & & $(0.16)$ & $(-1.44)$ & $(1.74)$ & $(0.07)$ & $(1.02)$ \\
\hline \multirow[t]{2}{*}{ Duration of listing } & + & -0.01 & 0.10 & 0.01 & -0.07 & 0.01 \\
\hline & & $(-0.06)$ & (1.49) & $(0.09)$ & $(-1.00)$ & $(0.27)$ \\
\hline \multirow[t]{2}{*}{ Foreign information factor } & + & $-0.14^{* *}$ & $0.02 * *$ & -0.08 & -0.02 & 0.04 \\
\hline & & $(-2.65)$ & $(2.28)$ & $(-1.07)$ & $(-0.39)$ & $(0.72)$ \\
\hline \multicolumn{7}{|l|}{ Control variables } \\
\hline \multirow[t]{2}{*}{ Company size } & + & $-0.65 * *$ & $-0.36 *$ & 0.20 & $0.47 * *$ & 0.14 \\
\hline & & $(-2.62)$ & $(-1.71)$ & $(0.88)$ & $(2.11)$ & $(0.68)$ \\
\hline Growth opportunities & + & $0.11 * *$ & $-0.003^{* *}$ & $-0.16^{* *}$ & 0.01 & $-0.21^{* *}$ \\
\hline & & $(2.50)$ & $(-2.60)$ & $(-2.34)$ & $(1.50)$ & $(-2.14)$ \\
\hline $\mathrm{N}$ foreign listings & - & $-0.92 * * *$ & 0.23 & $-0.39 *$ & $-0.58 * *$ & -0.24 \\
\hline & & $(-3.33)$ & (1.61) & $(-1.83)$ & $(-2.52)$ & $(-1.22)$ \\
\hline Intercept & & $22.15^{* * *}$ & 3.55 & 1.50 & $8.38 *$ & $-38.02 *$ \\
\hline & & (3.37) & $(0.91)$ & $(0.25)$ & $(1.74)$ & $(-1.69)$ \\
\hline Year-fixed effects & & YES & YES & YES & YES & YES \\
\hline $\mathrm{N}$ of observations & & 1,665 & 3,326 & 3,354 & 4,327 & 640 \\
\hline Adj. R-sq & & 0.77 & 0.53 & 0.72 & 0.48 & 0.77 \\
\hline
\end{tabular}

The table reports the OLS estimates of equation (2) separately for individual European host markets: $\operatorname{Ln}\left(F T V S_{i, n, t} /\left(1-F T V S_{i, n, t}\right)=\gamma_{0}+\sum_{j=1}^{J} \gamma_{j} X_{j, i, n, t}+\varepsilon_{i, t}\right.$, where $F T V S_{i, n, t}$ is the foreign trading volume share and the vector $X_{j, i, n, t}$ represents the determinants of the foreign trading volume distribution. All variables are defined in Appendix A. t-statistics (reported in parentheses) are heteroskedasticity consistent (White, 1980) and adjusted for clustering at the stock level. $* * *, * *$ and * indicate significant at $1 \%, 5 \%$ and $10 \%$ respectively. 
Appendix A. Variables' definitions and data sources

\begin{tabular}{|c|c|c|}
\hline & $\begin{array}{l}\text { Definition } \\
\end{array}$ & Data source \\
\hline \multicolumn{3}{|l|}{ Dependent Variable } \\
\hline $\begin{array}{l}\text { Foreign trading volume } \\
\text { share } F T V S_{i, n, t}\end{array}$ & $\begin{array}{l}\text { Foreign trading volume share, calculated as the monthly } \\
\text { ratio of the number of shares traded in a foreign market } \\
\text { divided by the total number of shares traded in the same } \\
\text { month in all markets in the sample, including the stock's } \\
\text { home market and foreign markets where the stock is listed. } \\
\text { Defined in equation (1): } \\
\qquad F T V S_{i, n, t}=\frac{N S T_{i, n, t}}{N S T_{i, d, t}+\sum_{n} N S T_{i, n, t}} \\
\qquad(1) \\
\text { where } N S T_{i, n, t} \text { is the number of shares of stock } i \text { traded on } \\
\text { foreign exchanges } n \text { during the month } t \text {, and } N S T_{i, d, t} \text { is the } \\
\text { number of shares of stock } i \text { traded on the home market } d \\
\text { during the month } t \text {. }\end{array}$ & $\begin{array}{l}\text { Trading volume data are } \\
\text { obtained from Datastream }\end{array}$ \\
\hline \multicolumn{3}{|l|}{ Fundamental factors } \\
\hline Return correlation & $\begin{array}{l}\text { Correlation coefficient of weekly stock returns and foreign } \\
\text { index returns over the preceding } 36 \text { (at least 24) months, } \\
\text { calculated for each month using rolling windows }\end{array}$ & Datastream \\
\hline Trading cost difference & $\begin{array}{l}\text { The difference in total trading costs, including explicit costs } \\
\text { (commissions) and implicit costs (price impact), between the } \\
\text { host and home markets }\end{array}$ & $\begin{array}{l}\text { Chiyachantana et al. (2004), } \\
\text { Table V }\end{array}$ \\
\hline Price per share & $\begin{array}{l}\text { The natural logarithm of the stock price on a particular } \\
\text { exchange converted to GBP, calculated for each month }\end{array}$ & Datastream \\
\hline Market size difference & $\begin{array}{l}\text { The log-difference between total market capitalization of the } \\
\text { host and home markets, calculated for each month }\end{array}$ & Datastream \\
\hline $\begin{array}{l}\text { Market turnover } \\
\text { difference }\end{array}$ & $\begin{array}{l}\text { The log-difference between the market turnover ratio of the } \\
\text { host and home markets, calculated for each month }\end{array}$ & Datastream \\
\hline $\begin{array}{l}\text { Same currency } \\
\text { indicator }\end{array}$ & $\begin{array}{l}\text { Dummy variable = } 1 \text { if foreign trading takes place in the } \\
\text { same currency as home trading; = } 0 \text { otherwise }\end{array}$ & Datastream \\
\hline Stock risk & $\begin{array}{l}\text { Standard deviation of stock's weekly returns over the } \\
\text { preceding } 12 \text { months, calculated for each month using } \\
\text { rolling windows }\end{array}$ & Datastream \\
\hline \multicolumn{3}{|l|}{ Informational factors } \\
\hline $\begin{array}{l}\text { Investor protection } \\
\text { difference }\end{array}$ & $\begin{array}{l}\text { The difference in investor protection index between the host } \\
\text { and home countries }\end{array}$ & La Porta et al. (2006) \\
\hline $\begin{array}{l}\text { Enforced insider } \\
\text { trading (IT) laws } \\
\text { difference } \\
\end{array}$ & $\begin{array}{l}\text { Dummy variable = } 1 \text { if insider trading laws have been } \\
\text { enforced in the foreign country but not in the home country; } \\
=0 \text { otherwise }\end{array}$ & $\begin{array}{l}\text { Bhattacharya and Daouk } \\
\text { (2002) }\end{array}$ \\
\hline Common language & $\begin{array}{l}\text { Dummy variable }=1 \text { if the host and home countries share a } \\
\text { common official language; }=0 \text { otherwise }\end{array}$ & $\begin{array}{l}\text { Sarkissian and Schill } \\
\text { (2004), available from S. } \\
\text { Sarkissian's website }\end{array}$ \\
\hline Geographic distance & $\begin{array}{l}\text { The natural logarithm of the geographic distance in } \\
\text { kilometres between capitals of the host and home countries }\end{array}$ & $\begin{array}{l}\text { Sarkissian and Schill } \\
\text { (2004), available from S. } \\
\text { Sarkissian's website } \\
\end{array}$ \\
\hline Foreign sales & $\begin{array}{l}\text { The fraction of foreign sales in the company's total net sales } \\
\text { in the preceding year, calculated for each month }\end{array}$ & Datastream \\
\hline
\end{tabular}




\begin{tabular}{|c|c|c|}
\hline Accounting standards & $\begin{array}{l}\text { Dummy variable = } 1 \text { if the company used international } \\
\text { accounting standards or US GAAP at the end of the } \\
\text { preceding year and = } 0 \text { otherwise, calculated for each month }\end{array}$ & Datastream \\
\hline Analyst coverage & $\begin{array}{l}\text { The number of the current 1-year EPS financial analysts' } \\
\text { forecasts, calculated for each month }\end{array}$ & Datastream \\
\hline Analyst forecast error & $\begin{array}{l}\text { The absolute value of the difference between the EPS } \\
\text { analysts' forecast and the matched actual EPS, scaled by the } \\
\text { absolute value of the actual EPS (Capstaff et al., 2001), } \\
\text { calculated for each month }\end{array}$ & $\begin{array}{l}\text { Forecasted and actual EPS } \\
\text { data are from Datastream }\end{array}$ \\
\hline Duration of listing & $\begin{array}{l}\text { The number of years a stock has been listed or traded on a } \\
\text { particular exchange, calculated for each month }\end{array}$ & $\begin{array}{l}\text { Calculated based on the } \\
\text { month and year of cross- } \\
\text { listing }\end{array}$ \\
\hline $\begin{array}{l}\text { Foreign information } \\
\text { factor }\end{array}$ & $\begin{array}{l}\text { Calculated using methodology of Baruch et al. (2007) as the } \\
\text { difference in R2 (adjusted for degrees of freedom) of a two- } \\
\text { index model including foreign market index and of a single- } \\
\text { index model with just the home market index. It is computed } \\
\text { for each month for each stock using weekly returns over the } \\
\text { preceding } 48 \text { (at least 36) months }\end{array}$ & Calculated \\
\hline \multicolumn{3}{|l|}{ Control variables } \\
\hline Company size & $\begin{array}{l}\text { The natural logarithm of the market value of the company's } \\
\text { common equity at the end of the preceding year, calculated } \\
\text { for each month }\end{array}$ & Datastream \\
\hline Growth opportunities & $\begin{array}{l}\text { Price-to-book value ratio at the end of the preceding year. If } \\
\text { not available from Datastream, it is calculated as the ratio of } \\
\text { the stock price to the company's book value per share, } \\
\text { calculated for each month }\end{array}$ & Datastream \\
\hline $\mathrm{N}$ foreign listings & $\begin{array}{l}\text { The number of foreign markets where the stock is traded, } \\
\text { calculated for each month }\end{array}$ & $\begin{array}{l}\text { Calculated based on the } \\
\text { foreign trading data in the } \\
\text { sample }\end{array}$ \\
\hline Host US & $\begin{array}{l}\text { Dummy variable }=1 \text { if trading takes place on the NYSE or } \\
\text { Nasdaq; = } 0 \text { otherwise }\end{array}$ & $\begin{array}{l}\text { The destination market for } \\
\text { cross-listing is collected as } \\
\text { part of the sample from } \\
\text { multiple data sources as } \\
\text { discussed in Section } 3.1\end{array}$ \\
\hline
\end{tabular}

